\title{
Temporal and spatial variability of glyoxal as observed from space
}

\author{
M. Vrekoussis ${ }^{1}$, F. Wittrock ${ }^{1}$, A. Richter ${ }^{1}$, and J. P. Burrows ${ }^{1,2}$ \\ ${ }^{1}$ Institute of Environmental Physics and Remote Sensing, IUP, University of Bremen, NW1, P.O. Box 3304 40, \\ 28334 Bremen, Germany \\ ${ }^{2}$ Centre for Ecology and Hydrology, Maclean Building, Benson Lane, Crowmarsh Gifford, Wallingford, Oxfordshire, \\ OX10 8BB, UK
}

Received: 16 March 2009 - Published in Atmos. Chem. Phys. Discuss.: 3 April 2009

Revised: 23 June 2009 - Accepted: 24 June 2009 - Published: 14 July 2009

\begin{abstract}
Glyoxal, CHO.CHO, is produced during the oxidation of volatile organic compounds, VOC, released by anthropogenic activities, biogenic processes and biomass burning. It has a short chemical lifetime of a few hours in the boundary layer and lower troposphere and therefore serves as an indicator and a marker of photochemical hotspots and their response to changing atmospheric conditions around the globe. For this reason more than five years of CHO.CHO observations (2002-2007), retrieved from the radiances measured by the satellite instrument SCIAMACHY, were obtained and analyzed both temporally and spatially. The largest columns of CHO.CHO $\left(>6.10^{14}\right.$ molec cm $\left.\mathrm{cm}^{-2}\right)$ are found in the tropical and sub-tropical regions, associated with high biological activity and the plumes from vegetation fires. The majority of the identified hot spots are characterized by a well-defined seasonality: the highest values being observed during the warm and dry periods as a result of the enhanced biogenic, primarily isoprene, emissions and/or biomass burning from natural or man-made fires. The regions influenced by anthropogenic pollution also encounter enhanced amounts of glyoxal. The ratio "CHO.CHO to $\mathrm{HCHO}, \mathrm{R}_{G F}$ " over the biogenically influenced photochemical hot-spots is approximately 0.045 . For the studied regions, the presence of pyrogenic and anthropogenic emissions increases and decreases this number respectively. Although the 2002-2007 period of observation is limited, over the northeastern Asia a significant annual increase in CHO.CHO in addition to a seasonal cycle is reported.
\end{abstract}

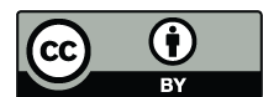

Correspondence to: $\mathrm{M}$. Vrekoussis (vrekoussis@iup.physik.uni-bremen.de)

\section{Introduction}

The emission of Volatile Organic Compounds (VOCs), released by a variety of processes at the Earth's surface, supplies reactive carbon containing compounds to the Earth's atmosphere. Tens of thousands of different VOCs exist in the air and as a result of their reactivity have highly variable but small mixing ratios such as a few tenths of parts per billion (ppbv) or per trillion (pptv). Their occurrence influences significantly atmospheric chemistry. VOCs are i) precursors of and provide the fuel for the formation of tropospheric ozone, $\mathrm{O}_{3}$ (Houwelling et al., 1998; Wang et al. 1998a, b; Poisson et al., 2001), ii) determine the oxidizing capacity of the troposphere (Monks, 2005), iii) play an important role in controlling the Secondary Organic Aerosols (SOA) formation (Tsigaridis and Kanakidou, 2003, 2007; Kanakidou et al., 2005; Tsigaridis et al., 2005; Volkamer at al., 2006) and iv) impact on the cloud condensation nuclei $(\mathrm{CCN})$ formation $(\mathrm{Yu}$, 2000; Roberts et al., 2002). The air pollution resulting from VOC chemistry has direct and indirect impacts on climate change (Ramanathan and Crutzen, 2003) and human health (Pope and Dockery, 2006). For all these reasons it is important to have an improved knowledge of the sources and the sinks of the VOCs and their oxidation.

\subsection{Sources of VOCs (general)}

Integrated over the globe, the emission of biogenic volatile organic compounds (BVOCs) overwhelms the release of VOC from anthropogenic sources: $1300 \mathrm{Tg}^{-1}$ of BVOCs are estimated to be emitted annually into the atmosphere in the form of species such as isoprene, terprenes and other oxygenated organic compounds from the biosphere whereas human sources release approximately $100 \mathrm{Tg} \mathrm{y}^{-1}$ (Williams, 2004). The majority of the man-made emissions originate from incomplete fossil fuel combustion in energy production,

Published by Copernicus Publications on behalf of the European Geosciences Union. 
transport and biomass burning. In addition significant release occurs from industrial facilities, solvent usage and oil refining.

Over the last decade an increasing effort has been made to identify the large number of VOC species present in the atmosphere and to quantify their emissions. The large variability of the fluxes of VOC to the atmosphere and their spatial distribution make the assessment and quantification of their role in atmospheric chemistry and climate change challenging. As the development of robust strategies to reduce $\mathrm{O}_{3}$ and aerosol levels requires the identification and quantification of VOCs, the observation of smaller molecules, which are produced in their oxidation and whose amount and distribution constrain the VOC fluxes to the atmosphere, offers a complementary approach to the measurement of VOC. The products of the VOC oxidation such as $\mathrm{HCHO}, \mathrm{CHO} . \mathrm{CHO}$, carbon monoxide $(\mathrm{CO})$ and even the ultimate carbon product of their oxidation, carbon dioxide, $\mathrm{CO}_{2}$, provide an opportunity to assess the total fluxes of VOC to the atmosphere. While the role of $\mathrm{CO}$ and $\mathrm{HCHO}$ in our efforts to understand the oxidation of species in the atmosphere has been given much attention, the use of CHO.CHO, for which the first measurements have only recently been reported, to constrain our understanding of the impact of VOC chemistry, remains relatively unexploited.

\subsection{Glyoxal sources}

CHO.CHO is one of the most prevalent carbonyl compounds in the atmosphere. It is the smallest alpha-dicarbonyl formed by chemical reactions following the initial elementary oxidation of VOC. The information about the distribution of direct or primary and indirect or secondary sources of $\mathrm{CHO} . \mathrm{CHO}$ is poor because of the scarcity of observations. Concerning primary sources Kean et al. (2001) and Grosjean et al. (2001) reported, during on-road measurements of carbonyl compounds at tunnels, that the emission factor of glyoxal ranges from 0.085 to $1.03 \mathrm{mg} \mathrm{L}^{-1}$ (or else $0.33 \mathrm{mg} / \mathrm{km}$ ) depending on the type of vehicles. This number, coming from the tailpipe emissions, is significantly lower than the one observed for $\mathrm{HCHO}$ which was up to $38 \mathrm{mg} \mathrm{L}^{-1}$ (Grosjean et al., 2001). One year later Hays et al. (2002) found that low molecular weight carbonyls such as $\mathrm{HCHO}$, $\mathrm{CHO}$. CHO, acetone, $\mathrm{CH}_{3} \mathrm{COCH}_{3}$, acetaldehyde, $\mathrm{CH}_{3} \mathrm{CHO}$ and methyglyoxal, $\mathrm{CH}_{3} \mathrm{CO}$. CHO, are the most abundant emission under foliar fuel combustion. It has been observed that $\mathrm{CHO}$. CHO emissions outweigh $\mathrm{HCHO}$ emissions by more than a factor of two.

Glyoxal is produced in the oxidation of precursor hydrocarbons having two or more carbon atoms (Calvert et al., 2000, 2002). The initial attack in the troposphere proceeds mainly through the $\mathrm{OH}$ radicals but to a lesser extent through $\mathrm{O}_{3}$ and nitrate radicals, $\mathrm{NO}_{3}$. A large fraction of the first generation CHO.CHO production $\left(P_{\mathrm{CHO}}\right.$.CHO $)$ (excluding potential primary sources) comes from the oxidation of biogenic
VOCs such as isoprene, and to a lesser extent monoterpenes, which account in total for $65-70 \%$ of the total $P_{\mathrm{CHO}}$.CHO (Fu et al., 2008; Myriokefalitakis et al., 2008). It should be noted though, that given the large uncertainty of estimates for the isoprene emission flux $\left(280-850 \mathrm{Tg} \mathrm{y}^{-1}\right.$; Wiedinmeyer et al., 2004; Guenther et al., 2006) $P_{\mathrm{CHO} . \mathrm{CHO}}$ (isoprene) has a large range. The same modeling studies point out that a significant portion of the $P_{\mathrm{CHO}} \mathrm{CHO}$ originates from anthropogenic sources; the oxidation of acetylene is the largest anthropogenic source of glyoxal accounting for $17-24 \%$ of the $P_{\text {CHO.сHO. }}$ Other anthropogenic sources are the oxidation of the aromatic VOCs, such as benzene, $\mathrm{C}_{6} \mathrm{H}_{6}$, toluene, $\mathrm{C}_{7} \mathrm{H}_{8}$ and xylene $\mathrm{C}_{8} \mathrm{H}_{10}$, which are believed to be responsible for $5-11 \%$ of $P_{\mathrm{CHO}}$.CHO. Additionally, non-negligible VOCs contributing to $P_{\mathrm{CHO}}$.CHO are ethylene, $\mathrm{C}_{2} \mathrm{H}_{4}$ and propylene, $\mathrm{C}_{3} \mathrm{H}_{6}$, which account for $2-7 \%$ of the global CHO.CHO source. In contrast, the $P_{\mathrm{CHO}}$.CHO from unsaturated $\gamma$ dicarbonyls, phenols and furanones appears to be negligible (Volkamer et al., 2001; Bloss et al., 2005). Additional sources of glyoxal may come from the aqueous oxidation of glycolaldehyde (in addition to the oxidation of other aldehydes) (Lim et al., 2005; Warneck et al., 2005). Other minor contributors are described within Fu et al. (2008) and Myriokefalitakis et al. (2008, and references cited therein).

Both modeling studies (Fu et al., 2008; Myriokefalitakis et al., 2008) underestimate the satellite glyoxal columns. A recent modeling study by Stavrakou et al. (2009b) pointed out that this underestimation could originate from a missing secondary source of glyoxal which accounts for about $50 \%$ of the global glyoxal budget.

\subsection{Glyoxal sinks}

Glyoxal is removed from the atmosphere via a variety of processes. The dominant sink is photolysis (Fu et al., 2008; Myriokefalitakis et al., 2008). Somewhat dependent on the modeling study, the oxidation of glyoxal initiated by $\mathrm{OH}$ radicals appears to be the next most important sink of CHO.CHO. Another important glyoxal sink is its potential role in the formation of secondary organic aerosol, SOA. Chamber experiments by Liggio et al. (2005a, b) showed that the uptake coefficient of the first order irreversible uptake of CHO.CHO by aqueous particles is about $10^{-3}$. In contrast, Kroll et al. (2005), pointed out that the particle growth did not occur while glyoxal was still present in the gas phase. This finding suggests that the uptake is reversible with no net contribution to SOA formation. More recently, a study (Volkamer et al., 2007) suggested that, lower experimental mixing ratios of $\mathrm{CHO}$.CHO in comparison to those predicted by the Master Chemical Mechanism, (Bloss et al., 2005) above Mexico City result from a missing sink: CHO.CHO being lost to SOA.

In addition, glyoxal can be removed by wet and dry deposition which together account for 9-15\% of the total losses (Fu et al., 2008; Myriokefalitakis et al., 2008). In both 
studies the global estimate of the computed chemical lifetime of CHO.CHO, based on the above mentioned sources and sinks, was, on average, about $3 \mathrm{~h}$. This means that glyoxal is short lived. The magnitude of the $\mathrm{CHO}$.CHO amount in an air mass is therefore a surrogate for the oxidation rate of VOCs. As the overwhelming majority of the VOC sources are close to the surface, the glyoxal in the boundary layer will dominate the column amount of CHO.CHO. Therefore glyoxal columns are a surrogate for the rate of VOC oxidation and large CHO.CHO columns can be used as a marker of air masses, which are photochemical "hot spots".

Previously, HCHO has been successfully used as an indicator of photochemical oxidation (e.g. Palmer et al., 2003, 2006; Wittrock et al., 2006; De Smedt et al., 2008; Müller et al., 2008). Glyoxal is arguably a better indicator of the rate of photochemical processing, because unlike $\mathrm{HCHO}$ it is not produced in the oxidation of methane, $\mathrm{CH}_{4}$. In addition the lower primary vehicle emissions of CHO.CHO as compared to those of $\mathrm{HCHO}$ make $\mathrm{CHO}$. CHO a better indicator for the oxidation of the anthropogenic VOCs in air masses polluted by traffic.

\subsection{Importance}

The aim of this study is to provide information on the spatial distribution and the temporal evolution of glyoxal as observed for the period 1 August 2002-31 December 2007, using measurements of the solar back scattered electromagnetic radiation upwelling from the top of the atmosphere by space based instrumentation. Inversion of these data yield observations of the temporal and spatial variation of $\mathrm{CHO}$.CHO. This, as already discussed, improves and tests our knowledge of the processes controlling the oxidizing capacity of the troposphere and also constrains our understanding on the different sources of emissions and their magnitude.

In the first section of this manuscript, the satellite instrument, the retrieval approach and the methods used to determine the atmospheric columns of glyoxal are described. This is followed by a comparison of the CHO.CHO columns retrieved in this way with the in situ ground-based observations of glyoxal found in the literature. Afterwards, the distribution of the vertical column densities of glyoxal is analyzed in terms of both spatial and temporal variability on i) a global scale and ii) over selected regions where high CHO.CHO values are encountered. The synergistic use of other short lived trace gas observations, such as $\mathrm{HCHO}$ and nitrogen dioxide, $\mathrm{NO}_{2}$, to characterize the origins of $\mathrm{CHO}$.CHO, i.e. emissions linked to anthropogenic activities, biogenic processes and biomass burning sources, is discussed.

\section{Instrumentation and methods}

\subsection{The SCIAMACHY instrument}

The SCIAMACHY (SCanning Imaging Absorption spectroMeter for Atmospheric CartograpHY) is an imaging UVVIS-near IR spectrometer, mounted on the ESA ENVISAT satellite, launched on the 28 February 2002. SCIAMACHY measures the transmitted, reflected and scattered light upwelling at the top of the atmosphere from the Earth's atmosphere and surface (Burrows et al., 1995; Bovensmann et al., 1999; Gottwald et al., 2006). ENVISAT flies in a sun synchronous, near polar orbit with a local equator crossing time of 10:00 a.m. in the descending node. It has three viewing geometries (Nadir, Limb and Solar Occultation). For the current study, the nadir mode having a spatial resolution of $30 \mathrm{~km}$ along track and $60 \mathrm{~km}$ across track $(60 \times 30 \mathrm{~km})$ was used. Global coverage is achieved for this viewing mode in about six days.

\subsection{Glyoxal spectral bands}

The highly resolved CHO.CHO absorption cross section $(\mathrm{FWHM}=0.001 \mathrm{~nm})$ (Volkamer et al., 2005) has been convolved with the SCIAMACHY spectral response, known as slit function (Fig. 1a). Glyoxal has strong absorption bands in the blue wavelength region $(420-460 \mathrm{~nm})$. The maximum absorption cross section value of the sharp CHO.CHO peak at $455 \mathrm{~nm}$ is $\sigma_{(\mathrm{CHO} . \mathrm{CHO})}=5.45 \times 10^{-19} \mathrm{~cm}^{2}$ molecules $^{-1}$.

These characteristic bands were recently used to retrieve glyoxal using absorption spectroscopy locally (e.g. Sinreich et al., 2007) as well as globally from space (Wittrock et al., 2006). The sharp and characteristic features of CHO.CHO absorption spectra are ideal for the use in the retrieval technique known as the differential optical absorption spectroscopy (DOAS) (Platt and Perner, 1980; Platt, 1994).

\subsection{DOAS technique and Slant Column Densities computation}

DOAS is a technique used for the discrimination of the characteristic higher frequency absorption structures of trace gases from the slowly varying broad band extinction processes such as Rayleigh and Mie scattering and broad band molecular absorption, as well as potential instrumental artifacts. To do so, a high pass polynomial filter, accounting for these broad band structures, is applied. The higher frequency spectral features are used to retrieve the trace gases absorptions known as slant column absorptions. These are converted to Slant Column Densities (SCD) by taking into account the relevant absorption cross sections. SCDs represent the amount of the trace gas along the average path taken by photons during their travel through the atmosphere and back to the satellite sensor. The quantitative determination of the SCDs is achieved by applying a non linear least square fitting procedure. 


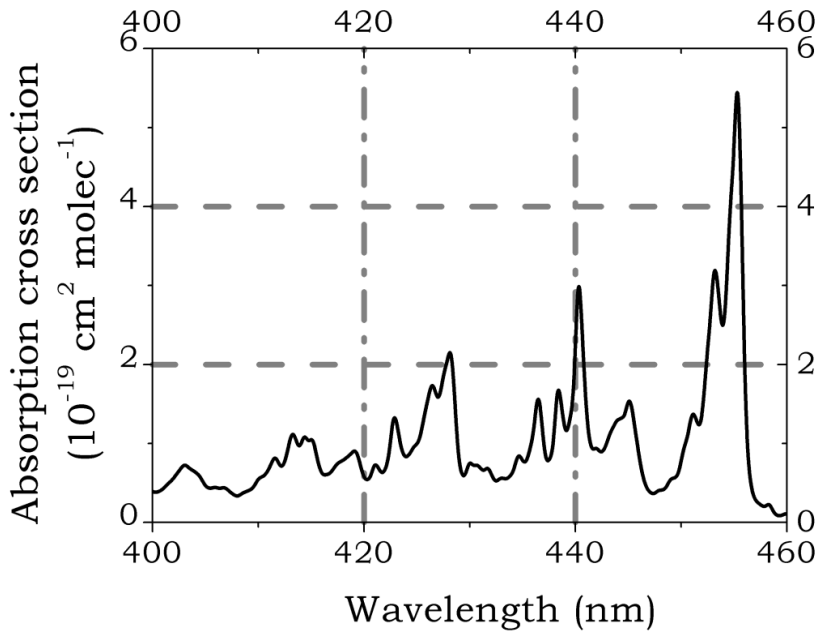

Fig. 1a. Highly resolved CHO.CHO absorption cross section (FWHM=0.001nm) (Volkamer et al., 2005) convoluted to the SCIAMACHY slit function (FWHM=0.5). The maximum absorption cross section value of the sharp CHO.CHO peak (at $455 \mathrm{~nm}$ ) is $\sigma_{(\mathrm{CHO} . \mathrm{CHO})}=5.45 \times 10^{-19} \mathrm{~cm}^{2}$ molecules $^{-1}$.

For the glyoxal retrieval the spectral window of 435 $457 \mathrm{~nm}$ has been chosen. The reason for excluding the spectral features of CHO.CHO around $420 \mathrm{~nm}$ is a large interference with Ring structures. These Ring structures arise from the infilling of Fraunhofer features in the scattered electromagnetic radiation by rotational Raman scattering on air molecules. The chosen wavelength window was found to be the optimal in terms of achieving reasonably small residuals and a good sensitivity to glyoxal. The reference absorption cross sections that were used in the retrieval process include CHO.CHO (Volkamer et al., 2005), and interfering species such as $\mathrm{O}_{3}$ (Bogumil et al., 1999), $\mathrm{NO}_{2}$ (Bogumil et al., 1999), $\mathrm{O}_{4}\left(\mathrm{O}_{2}-\mathrm{O}_{2}\right.$ collision) (Greenblatt et al., 1990), water vapour (HITRAN database, http://www.cfa. harvard.edu/hitran/), the pseudo-absorption features due to Rotational Raman Scattering (RRS) by air molecules (Ring effect, Vountas et al., 1998), the absorption of phytoplankton (Bracher and Tilzer, 2001; Vountas et al., 2007) and also a 4 th order polynomial. Figure $1 \mathrm{~b}$ shows a representative example of a DOAS fit of CHO.CHO for a ground scene above a smoke plume observed during intensive biomass burning above Greece, in August 2007. The blue dotted line shows the $\mathrm{CHO}$. CHO fitted result after removing all other absorbers. The black line depicts the scaled laboratory reference. The computed $\mathrm{SCD}_{\mathrm{CHO}}$.CHO for this case was $6.23 \times 10^{15} \mathrm{molec}^{-2}$, the estimated fitting error $7.9 \%$, with the chi-square value $5.1 \times 10^{-6}$.

\subsection{Impact of clouds on glyoxal observations}

The next step in the retrieval process is to account for the presence of clouds and their impact on the radiance up-



Fig. 1b. Representative example of a DOAS fit of glyoxal for a ground scene above a smoke plume observed during the intensive fires above Greece, on August 2007 (orbit:70826091). The blue dotted line is the CHO.CHO fitted result after removing all other absorbers and the black line depicts the scaled differential laboratory reference. The computed $\mathrm{SCD}_{\mathrm{CHO} \text {. } \mathrm{CHO}}$ to this case is $6.23 \times 10^{15}$ molec cm $^{-2}$.

welling from the top of the atmosphere and their shielding of the air containing trace gases below them. Scattering at the surface, by air molecules, aerosols and cloud impact on the absorption information carried by the photons reaching the top of the atmosphere by changing the light path through the atmosphere and the number of photons upwelling from the atmosphere. If a gas is heterogeneously distributed within a ground scene then the different surface spectral reflectance from different part of the ground scene have different weightings.

Clouds can be described as complex scattering volume diffusers of electromagnetic radiation within the atmosphere having high surface spectral reflectance. Therefore they alter the light path through the troposphere. Ideally the distribution of the trace gas being measured above, within and below the cloud needs to be accounted for explicitly to enable the air mass factors to be determined accurately (see the considerations in Richter and Burrows, 2002). In this context two different extreme scenarios are worth being considered for CHO.CHO;

1. all the CHO.CHO is found under the clouds. In this case neglecting these effects results in the cloud shielding the lower atmosphere and leads to a) an underestimation of CHO.CHO in the cloudy part of the scene b) an underestimation of the CHO.CHO in the full ground scene;

2. all the CHO.CHO is found above cloud top height. In this case as a result of the large surface spectral reflectance, an overestimation of the CHO.CHO above the cloud compared to that in the cloud part of the scene is 
observed. This case is anticipated to be a rare possibility.

As photochemistry in and below the cloud is reduced, and CHO.CHO is hydrophilic, the source of CHO.CHO is advection from source region and convection within the cloud. In addition multiple scattering further complicates the analysis. For the ground scene criteria of $<20 \%$ cloud within the scene, there is a distribution of cloud, which means the average cloud in a scene is significantly less than the $20 \%$ and include thin clouds. The multiple scattering within these scenes are in part dealt with the selection of aerosol for the AMF calculation (see Sect. 2.5).

In the outflow from pollution hot spots and biomass burning, which have active photochemistry and sufficiently long lived VOCs, the CHO.CHO above the cloud and above the same height as the cloud in the cloud free part of the scene are likely to be similar if the wind speed is sufficiently large.

Summarizing our assessment for ground scenes having less than $20 \%$ cloud is that a) It is overall most probable that there are only small amounts of CHO.CHO below and within the cloud and, b) the number of these scenes, where significant differences between the air above the clouded and cloud free parts of the scene are small. For the current analysis the ground scenes having cloud coverage less than $20 \%$ were considered by applying an intensity filter criterion. Stricter intensity criterion will reduce the uncertainties emanating from clouds but it will also reduce the number of observations. So this is considered to be a pragmatic compromise. The consequences are that the results of the analysis are biased to cloud free atmospheric conditions. In addition changes of cloud or for that matter aerosol within the ground scenes having $<20 \%$ of the ground scene influence our assessment of the magnitude of the CHO.CHO column and any change. For the present the data has been analyzed without attempting to separate the change induced by small changes in cloud and aerosol.

Future retrieval algorithms will take into account the aerosol and clouds more explicitly using synergistic measurements of clouds and aerosol from the other instruments aboard ENVISAT. At present we consider that as a result of relatively small amounts of $\mathrm{CHO} . \mathrm{CHO}$ within and below a cloud adding that solutions such as a "ghost column" for the cloudy part of the ground scene introduces another source of error in the VCD determination.

\subsection{Air Mass Factors and Vertical Column Densities computation}

The obtained SCDs are converted to Vertical Column Densities (VCDs) after applying the air mass factors (AMF), which is defined as the ratio of the SCD/VCD and depends on the radiative transfer properties of the atmosphere. The AMF is a function of many parameters such as the surface spectral reflectance of the observed ground scene, the surface pressure, the viewing geometry, the clouds, the aerosol vertical distribution and its optical thickness, the solar zenith angle and finally, the vertical distribution of CHO.CHO in the lowermost troposphere. For this study, the block air mass factors from Wittrock (2006) were used. These AMF calculations using the radiative transfer model SCIATRAN (Rozanov, 2005, and references therein), which takes into account all the above mentioned parameters. The resultant global annual mean composite glyoxal air mass factors are shown in Fig. 2b. As illustrated in this figure, the mean value of AMF on a global scale is about 2 . There are several regions where this value is lower for example where the visibility is reduced significantly (e.g. above areas of biomass burning and industrialized areas) or higher as a result of high surface spectral reflectance or albedo in the spectral window selected (e.g. Polar Regions).

\subsection{Glyoxal detection limit and error analysis}

For cloud free scenes, the accuracy of the Vertical Column Densities of CHO.CHO retrieved from SCIAMACHY measurements depends on several individual errors which can be systematic and/or random in origin.

The systematic errors comprise

1. The error on the knowledge of the trace gas absorption cross sections and their temperature dependence

2. the atmospheric temperature

3. instrumental errors (e.g. wavelength calibration),

4. errors in air mass factor calculations, offset errors and

5. correlation errors (e.g. interference with Ring spectral features).

Many of these errors are estimated to be on the order of a few percent (Wittrock, 2006). The largest error is induced by differences between the climatological values used as input to the AMF calculation and reality, e.g. the assumed vertical profile of aerosol and residual cloud.

The random errors comprise the noise on the measured backscattered electromagnetic radiation as a function of wavelength range relative to the measured absorption.

In order to calculate the detection limit of the slant column densities the simple approximation of an ideal measurement is considered; the SCD should be at least larger than the ratio of the root mean square noise (RMS) of the optical density, $\left(\ln \left(\mathrm{I}_{o} / \mathrm{I}\right)\right.$, to the absorption cross section of the species of interest, $\mathrm{SCD}_{\lim } \geq \frac{\mathrm{RMS}}{\sigma_{\mathrm{CHO}} \mathrm{CHO}}$. The typical RMS value of SCIAMACHY at the wavelength region of $450 \mathrm{~nm}$ is $3.3 \times 10^{-4}$. Taking into account that the maximum absorption cross section of $\mathrm{CHO}$. CHO is $\sigma_{(\mathrm{CHO} . \mathrm{CHO})}=5.5 \times 10^{-19} \mathrm{~cm}^{2} \mathrm{molec}^{-1}$ the individual slant column density limit is $6.0 \times 10^{14} \mathrm{molec} \mathrm{cm}^{-2}$. It should be noted that the systematic error based on the estimations of Wittrock, 2006 is about $4.0 \times 10^{14}$ molec $^{-2}$. The random 

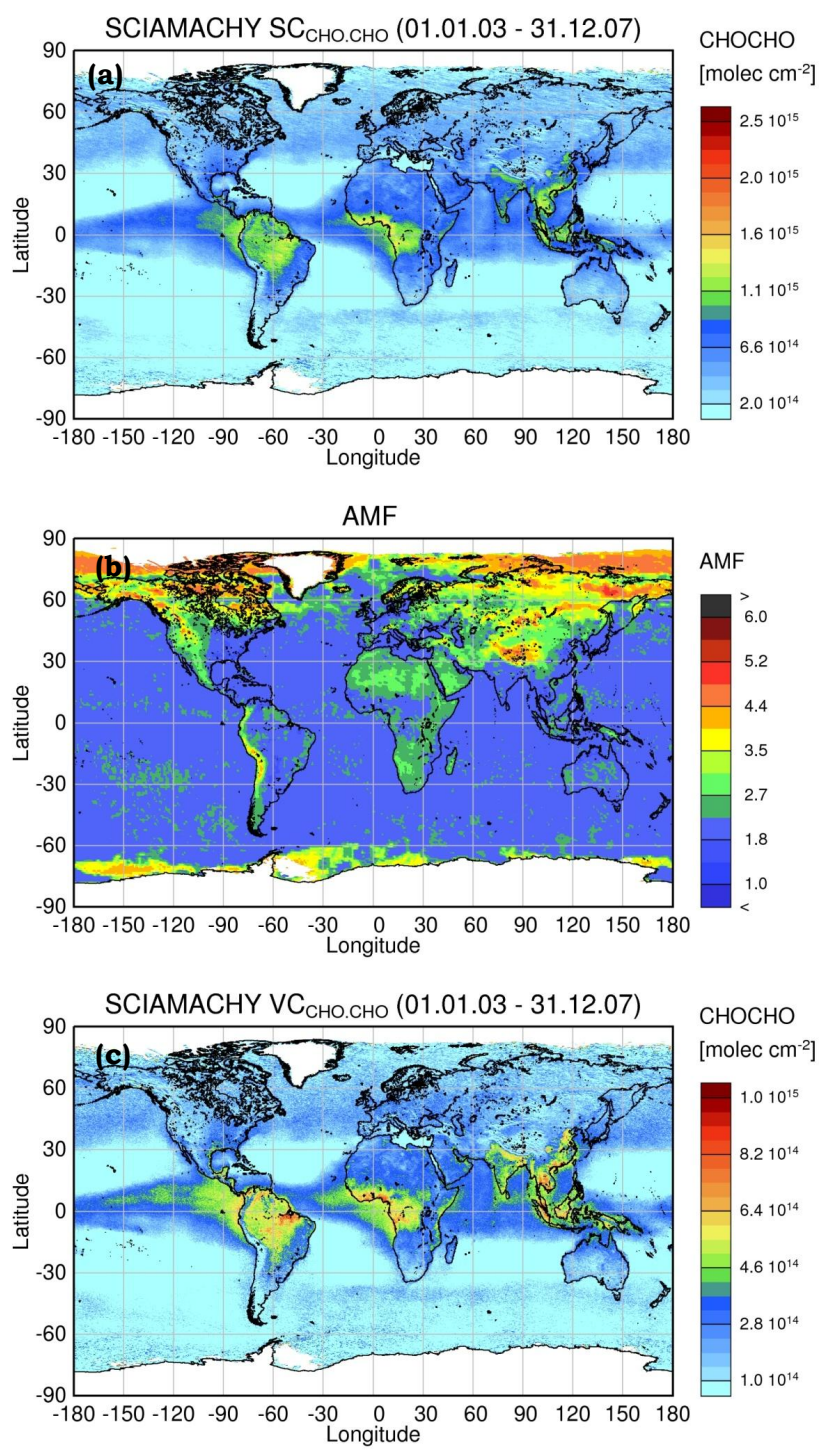

Fig. 2. (a) SCD: Multiannual composite map of the glyoxal slant column densities retrieved from the radiance measurements from the SCIAMACHY instrument. (b) AMF: Multiannual composite map of the air mass factors computed with the radiative transfer model SCIATRAN. (c) Multiannual composite map of the glyoxal vertical column densities computed from the ratio SCD/AMF. The largest amounts of CHO.CHO are found over the tropical and subtropical latitudes which are characterized by vegetation and fire emissions of volatile organic compounds.

limit reduces when averaging in space and time, assuming Poisson statistics.

Nevertheless this averaging has a direct impact on the spatial and temporal resolution of the data. For this study, the monthly means of $\mathrm{VCD}_{\mathrm{CHO}}$.CHO were used. For these monthly composites of cloud free scenes (cloud fraction $<20 \%$ ) the total uncertainty is given by:

$\left[2 \times 10^{14}+X \mathrm{VC}_{\mathrm{CHO} . \mathrm{CHO}}\right]\left(\right.$ molec $\left.^{-2}\right)$
The additive term is determined by the minimum detectable absorption of $\mathrm{CHO}$.CHO assuming non-systematic errors only. The value of $X$ is strongly ground scene dependent but varies typically in the range 0.1 to 0.3 . A detailed description of the systematic error sources is presented elsewhere (Wittrock, 2006; Wittrock et al., 2006).

\section{Results and discussion}

\subsection{Global VCD CHO.CHO levels $_{\text {. }}$}

In the current study, a data set comprising more than five years (August 2002-December 2007) of SCIAMACHY observations of $\mathrm{CHO}$. $\mathrm{CHO}$ has been generated. As the stratospheric column of $\mathrm{CHO}$. $\mathrm{CHO}$ is negligible, this data set

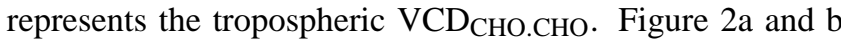
shows the glyoxal slant column densities and the air mass factors used in this study to determine the VCD. For both figures the multi-annual average for the time span of 2003-2007 has been taken into account to obtain five complete years of measurements.

Enhanced glyoxal column amounts of $\mathrm{SCD}_{\mathrm{CHO} . \mathrm{CHO}} \geq$ $1.2 \times 10^{15}$ molec cm $^{-2}$ (Fig. 2a) and $\mathrm{VCD}_{\mathrm{CHO} . \mathrm{CHO}} \geq 6 \times$ $10^{14}$ molec cm $^{-2}$ (Fig. 2c) have been observed. The majority of the areas having enhanced glyoxal columns are in tropical and sub-tropical regions. South America, Africa, India, Indonesia and Asia (mainly South-Eastern China) are among the regions where high values of CHO.CHO are retrieved. At middle latitudes, moderate values of

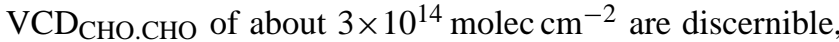
for example above North America, Europe and Australia. Notably, high column amounts of $\mathrm{CHO}$. CHO are also found above water, close to upwelling areas and regions having significant amounts of phytoplankton as indicated by their ocean colour. This implies oceanic biogenic activity as a possible source of glyoxal precursors (this is discussed further in Sect. 3.5.7).

Due to the short lifetime of CHO.CHO of about 2-3h, these high values are expected to originate mostly from regional sources of the precursor VOCs. Indeed, as it will be described later on (Sect. 3.5) depending on the season, these regions are characterized by strong biogenic emissions, biomass burning and pollution induced from anthropogenic activities.

\subsection{Comparison of space observations and ground based measurements}

A comparison of the data set of the glyoxal retrieved from SCIAMACHY with the ones published involving in situ ground based measurements was undertaken in this study. In Table 1 the CHO.CHO mixing ratios reported in the literature are compiled. The air masses over these measuring sites are characterized as polluted-urban, polluted semi-urban, rural (sometimes influenced by urban plumes) and maritime. 


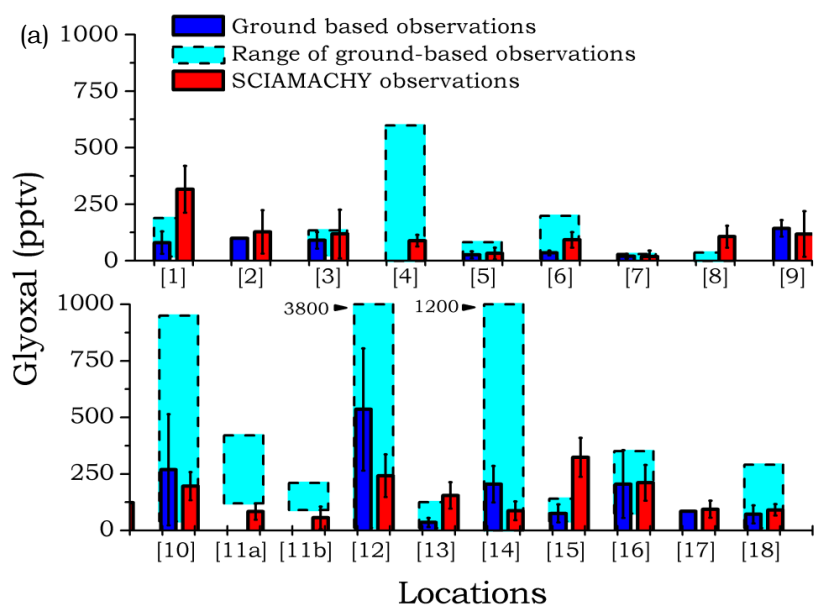

Fig. 3a. Comparison of the in situ observations (blue bars) with the converted space based observations (red bars) using the assumptions stated in the text. The cyan bars depict the range of the ground based measurements. In some of the references the range and not the actual value is reported. The numbers of the locations correspond to the measuring stations used in Table 1.

Unfortunately, no observations are available for the Southern Hemisphere, where high concentrations of $\mathrm{CHO} . \mathrm{CHO}$ are observed from space.

In order to compare directly the in situ measurements of glyoxal mixing ratios with the space based observations of tropospheric columns of CHO.CHO several assumptions had to be made. For example, it has been assumed that CHO.CHO is well mixed inside the boundary layer which has been calculated from the LMDz-INCA model for the year 2000 (K. Tsigaridis, personal communication). For the conversion of the vertical column densities, standard conditions of temperature and pressure $\left(25^{\circ} \mathrm{C}\right.$ and $\left.1 \mathrm{~atm}\right)$ have been used.

The spatial resolution of the SCIAMACHY instrument $(30 \times 60 \mathrm{~km})$ is large in comparison to the point of the in-situ measurements. We assume for the present that the point measurements are representative for a box of dimensions $1^{\circ} \times 1^{\circ}$ surrounding each station.

Finally, the in situ observations were considered to be representative for the whole season that they were conducted, regardless of the actual year of measurements. The reasons are that i) the time series of the SCIAMACHY glyoxal data set is limited from August 2002 and on so no direct comparison is feasible with the older in situ data-sets and ii) the satellite overpass above a specific point occurs only a few times per month and averaging of data is necessary.

The outcome of the comparison is visualized in Fig. 3a and b. As depicted in Fig. 3a, there is a reasonable agreement of the SCIAMACHY observations (red bars) with the ground based observations (blue bars) when taking into account their range (cyan columns), their standard deviation,

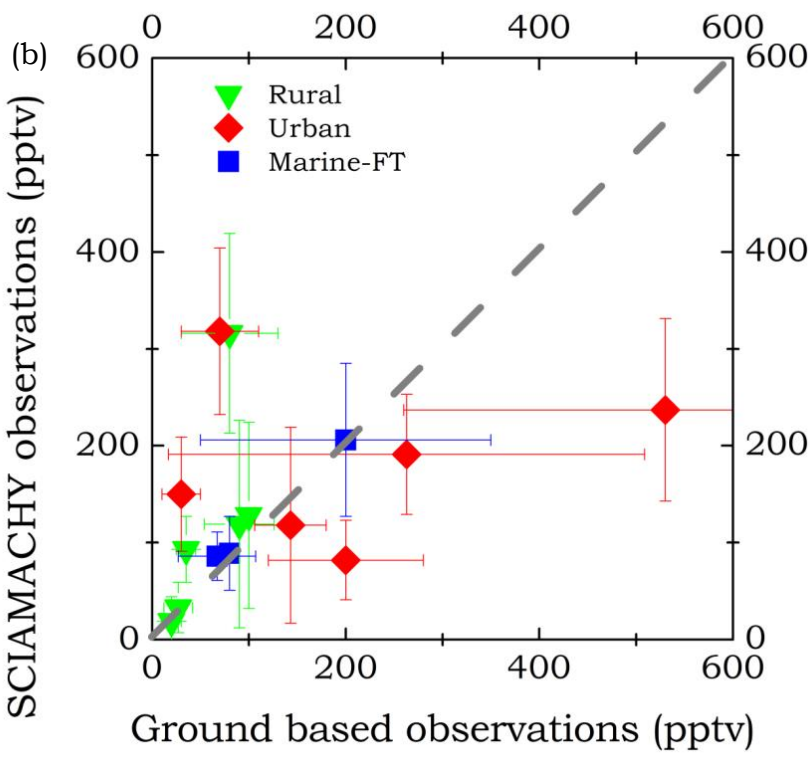

Fig. 3b. Comparison of the SCIAMACHY observations with the ground-based rural (green triangles), urban (red rhombs) and marine (blue squares) measurements coupled with their standard deviations.

the numerous assumptions made and the different techniques used. In most of the cases (Fig. 3b) SCIAMACHY overestimates the in situ measurements which would be explained by the transport of glyoxal above the boundary layer over constant sources e.g. isoprene emissions over the rural stations. There are a few cases, above urban areas, where SCIAMACHY underestimates the measurements and this could be due to the dilution of the localized anthropogenic emissions to the $1^{\circ} \times 1^{\circ}$ box chosen for the SCIAMACHY analysis. Interestingly, SCIAMACHY agrees well with the moderate values observed over the ocean (Zhou et al., 1990; Sinreich et al., 2007) and the only reported aircraft observations, of CHO.CHO mixing ratios (Lee et al., 1998) over Nashville, USA.

\subsection{Interannual variability of glyoxal vertical column densities}

The global distribution of the yearly averaged glyoxal columns between 2003 and 2007 is displayed in Fig. 4. A similar pattern is observed, systematically, every year. Each individual composite map of $\mathrm{VCD}_{\mathrm{CHO}}$.CHO confirms that high column amounts are found above regions with dense vegetation (e.g. the tropical forest of Amazonia), biomass burning (e.g. the sub-Saharan Africa) and anthropogenic emissions (e.g. Guangzhou, China) and those having mixtures of these three sources of VOC. In order to compute the annual changes of glyoxal on a global scale, a linear regression of the annual averages of tropospheric CHO.CHO was applied and plotted in Fig. 5a. In addition, 

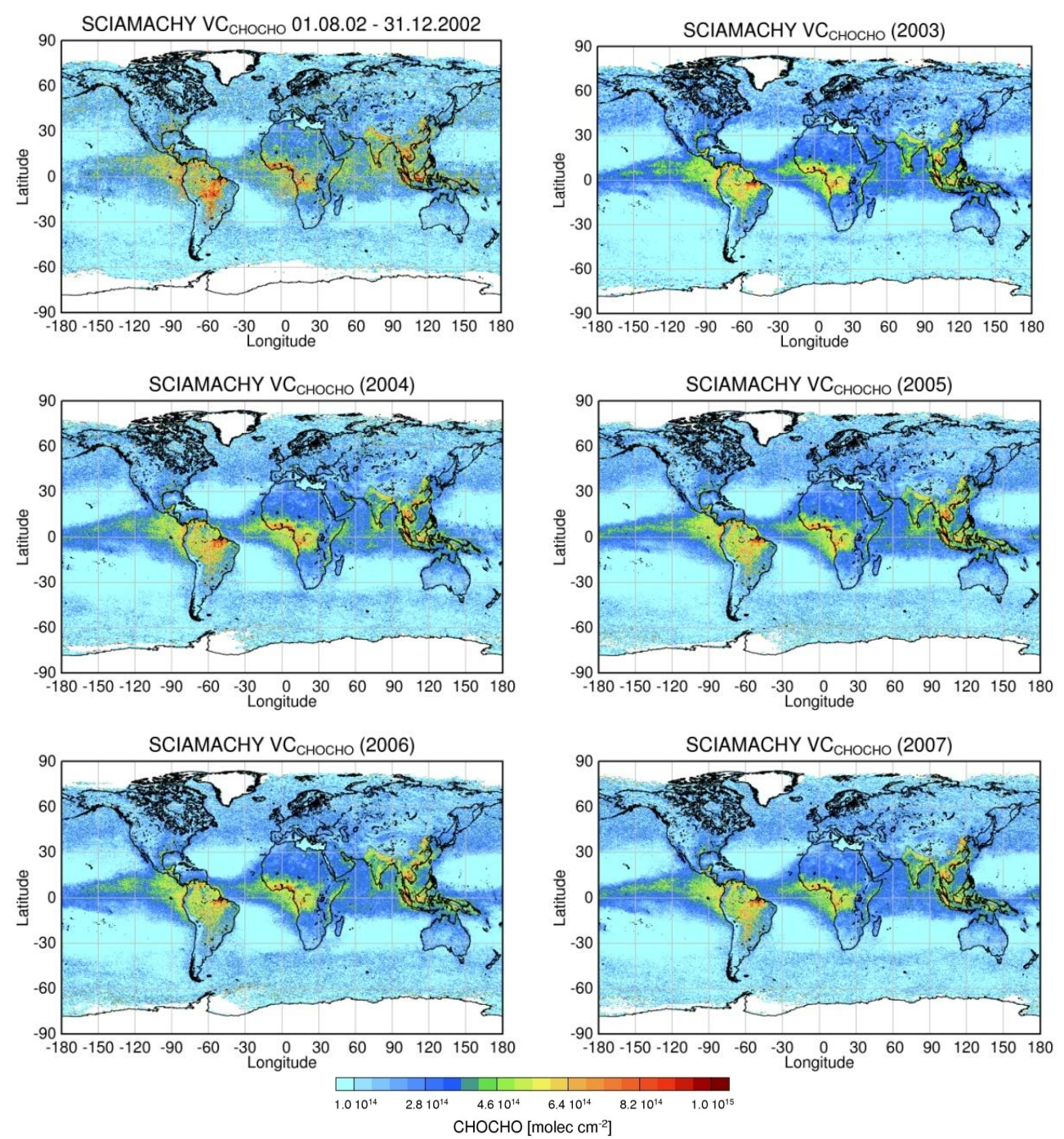

Fig. 4. $\mathrm{VC}_{\mathrm{CHO}}$. СHO per year: Yearly averaged glyoxal vertical columns $\left(\right.$ molec $\left.\mathrm{cm}^{-2}\right)$ from 2003 to 2007 . This figure includes also the half year observations obtained during the period August 2002-December 2002.
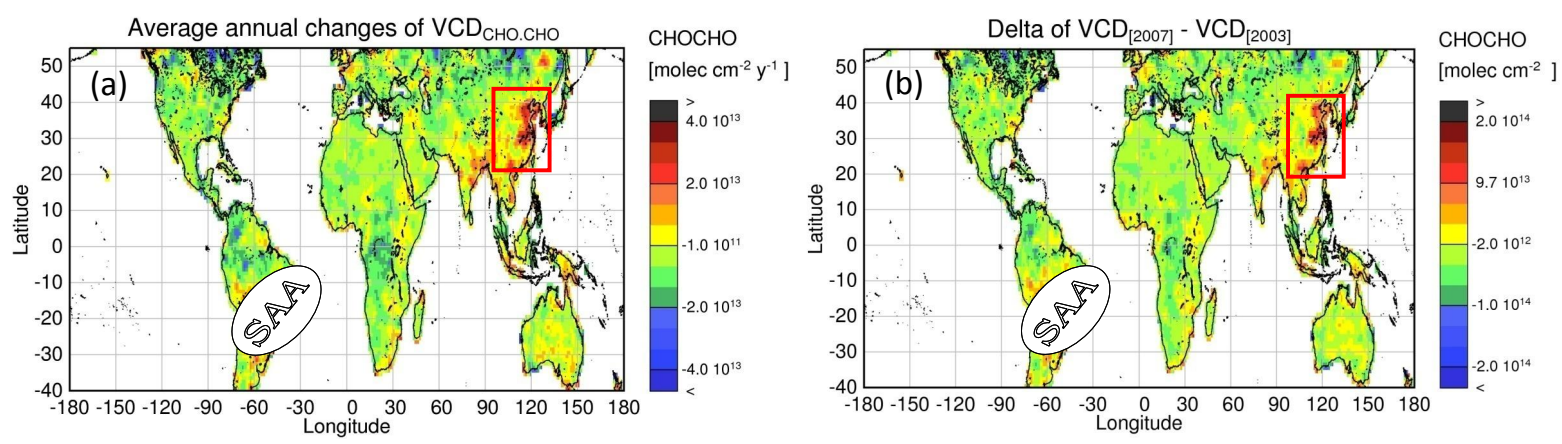

Fig. 5. Absolute and respective differences. Linear regression (panel a) of the annual averages of the glyoxal vertical columns retrieved for the period 2003-2007 and the difference (panel b) of the CHO.CHO vertical columns retrieved for the years 2007 and 2003. The red color denotes an increase while the blue one shows a decrease in respective $\mathrm{VCD}_{\mathrm{CHO}} \mathrm{CHO}$ values. The SAA corresponds to the South Atlantic Anomaly and the values are not considered in this study because they have more noise. Significant increases of the rate of emission of glyoxal is observed over China. 
Table 1. Glyoxal concentrations in rural, semi-polluted, polluted and marine sites. The SCIAMACHY vertical columns were converted to mixing ratios using some basic assumptions noted in the caption.

\begin{tabular}{|c|c|c|c|c|c|}
\hline Location & Comment & $\begin{array}{l}\text { Period } \\
\text { [season] }\end{array}$ & $\begin{array}{l}\text { Mixing ratio } \\
{[p p t v]}\end{array}$ & 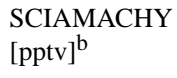 & Reference \\
\hline $\begin{array}{l}\text { [1] Metter, Georgia, USA } \\
\left(32^{\circ} \mathrm{N}, 82^{\circ} \mathrm{W}\right)\end{array}$ & Rural & Summer & $\begin{array}{l}80 \pm 60^{\mathrm{a}} \\
\text { Range: } 20-190\end{array}$ & $316 \pm 103$ & Lee et al. (1995) \\
\hline $\begin{array}{l}\text { [2] San Nicolas, Ventura, USA } \\
\left(33^{\circ} \mathrm{N}, 119^{\circ} \mathrm{W}\right)\end{array}$ & Rural & Autumn & 100 & $128 \pm 96$ & Grosjean et al. (1996) \\
\hline $\begin{array}{l}\text { [3] Tamakomai forest, Hokkaid, } \\
\text { Japan } \\
\left(43^{\circ} \mathrm{N}, 142^{\circ} \mathrm{E}\right)\end{array}$ & Rural & Autumn & $\begin{array}{l}90 \pm 36^{\mathrm{a}} \\
\text { Range: } 26-136\end{array}$ & $119 \pm 107$ & Ieda et al. (2006) \\
\hline $\begin{array}{l}\text { [4] Anadia, Portugal } \\
\left(40^{\circ} \mathrm{N}, 8^{\circ} \mathrm{W}\right)\end{array}$ & Rural & Summer & Range: $0-600$ & $89 \pm 26$ & Cerqueira et al. (2003) \\
\hline $\begin{array}{l}\text { [5] Blodgett forest, California, USA } \\
\left(39^{\circ} \mathrm{N}, 120^{\circ} \mathrm{W}\right)\end{array}$ & Rural, 1315 m & Summer & $\begin{array}{l}27 \pm 15 \\
\text { Range: } 6-83\end{array}$ & $33 \pm 26$ & Spaulding et al. (2003) \\
\hline $\begin{array}{l}\text { [6] Pinnacles, Shenandoah Park, } \\
\text { Virginia, USA } \\
\left(39^{\circ} \mathrm{N}, 78^{\circ} \mathrm{W}, 1037 \mathrm{~m}\right)\end{array}$ & $\begin{array}{l}\text { Rural } \\
\text { (mountain site - } \\
1037 \mathrm{~m} \text { ) }\end{array}$ & Autumn & $\begin{array}{l}35 \pm 10^{\mathrm{a}} \\
\text { Range: } 10-200\end{array}$ & $93 \pm 34$ & Munger et al. (1995) \\
\hline $\begin{array}{l}\text { [7] Goldlauter, Germany } \\
\left(55^{\circ} \mathrm{N}, 11^{\circ} \mathrm{E}\right)\end{array}$ & Rural, $605 \mathrm{~m}$ & Autumn & $\begin{array}{l}20 \pm 10^{\mathrm{a}} \\
\text { Range: } 4-31\end{array}$ & $19 \pm 25$ & Müller et al. (2005) \\
\hline $\begin{array}{l}\text { [8] Lassen, California, USA } \\
\left(38^{\circ} 5^{\prime} \mathrm{N}, 121^{\circ} \mathrm{W}\right)\end{array}$ & Rural, $2070 \mathrm{~m}$ & Summer/Autumn & Range: $0-38$ & $106 \pm 48$ & Seaman et al. (2006) \\
\hline $\begin{array}{l}\text { [9] Roseville, California, USA } \\
\left(38^{\circ} 5^{\prime} \mathrm{N}, 121^{\circ} \mathrm{W}\right)\end{array}$ & Sub-urban & Summer/Autumn & $143 \pm 37$ & $118 \pm 101$ & Seaman et al. (2006) \\
\hline $\begin{array}{l}\text { [10] LA, USA, } \\
\left(34^{\circ} \mathrm{N}, 117^{\circ} \mathrm{W}\right)\end{array}$ & Polluted/urban & Autumn & $\begin{array}{l}263 \pm 246 \\
\text { Range: } 40-950\end{array}$ & $191 \pm 62$ & Kawamura et al. (2000) \\
\hline $\begin{array}{l}{[11 \mathrm{a}][11 \mathrm{~b}] \text { Las Vegas, USA }} \\
\left(36^{\circ} \mathrm{N}, 115^{\circ} \mathrm{W}\right)\end{array}$ & Polluted/urban & $\begin{array}{l}\text { Summer } \\
\text { Winter }\end{array}$ & $\begin{array}{l}\text { Range: } 120-420 \\
\text { Range: } 90-210\end{array}$ & $\begin{array}{l}78 \pm 35 \\
51 \pm 50\end{array}$ & Jing et al. (2001) \\
\hline $\begin{array}{l}\text { [12] Long Beach, LA, Claremont, } \\
\text { Azusa, California, USA } \\
\left(34^{\circ} \mathrm{N}, 117^{\circ} \mathrm{W}\right)\end{array}$ & Polluted/urban & Autumn & $\begin{array}{l}530 \pm 270^{\mathrm{a}} \\
\text { Range: } 12-3800\end{array}$ & $237 \pm 94$ & Grosjean et al. (1996) \\
\hline $\begin{array}{l}\text { [13] Pabstthum, Germany } \\
\left(52^{\circ} 5^{\prime} \mathrm{N}, 12^{\circ} 5^{\prime} \mathrm{E}\right)\end{array}$ & Polluted/urban & Summer & $\begin{array}{l}30 \pm 20^{\mathrm{a}} \\
\text { Range: } 10-125\end{array}$ & $150 \pm 59$ & Moortgat et al. (2002) \\
\hline $\begin{array}{l}\text { [14] Mexico City, Mexico } \\
\left(19^{\circ} 3^{\prime} \mathrm{N}, 19^{\circ} 1^{\prime} \mathrm{W}\right)\end{array}$ & Polluted/urban & Spring & $\begin{array}{l}200 \pm 80^{\mathrm{a}} \\
\text { Range: } 0-1200\end{array}$ & $82 \pm 41$ & Volkamer et al. (2005) \\
\hline $\begin{array}{l}\text { [15] MIT, Massachusetts, USA } \\
\left(42^{\circ} 4^{\prime} \mathrm{N}, 71^{\circ} 1^{\prime} \mathrm{W}\right)\end{array}$ & Polluted/urban & Summer & $\begin{array}{l}70 \pm 40^{\mathrm{a}} \\
\text { Range: } 40-140\end{array}$ & $318 \pm 86$ & Sinreich et al. (2007) \\
\hline $\begin{array}{l}\text { [16] Gulf of Maine, } \\
\left(43^{\circ} \mathrm{N}, 68^{\circ} \mathrm{W}\right)\end{array}$ & Marine/polluted & Summer & $\begin{array}{l}200 \pm 150^{\mathrm{a}} \\
\text { Range: } 75-350\end{array}$ & $206 \pm 79$ & Sinreich et al. (2007) \\
\hline $\begin{array}{l}\text { [17] Caribbean Sea and Sargasso } \\
\text { Sea coast } \\
\left(15^{\circ} \mathrm{N}, 66^{\circ} \mathrm{W}\right)\end{array}$ & Marine & Autumn-Spring & 80 & $89 \pm 38$ & Zhou and Mopper (1990) \\
\hline $\begin{array}{l}\text { [18] Nashville, Tennessee, USA } \\
\left(37^{\circ} \mathrm{N}, 87^{\circ} \mathrm{W}\right)\end{array}$ & Free troposphere & Summer & $\begin{array}{l}67 \pm 40, \\
\text { range: } 10-290 \\
\text { (inside the BL) }\end{array}$ & $86 \pm 25$ & Lee et al. (1998) \\
\hline
\end{tabular}

a At around 10 a.m. as calculated from the cited diurnal variation when available

$\mathrm{b}$ The conversion of the column densities to pptv is performed by assuming that most of the observed CHO.CHO is found inside the boundary layer. For simplicity reasons, standard conditions for temperature $\left(25^{\circ} \mathrm{C}\right)$ and pressure $(1 \mathrm{~atm})$ were used in the calculations. In addition, it was assumed that the ground based measurements are representative for the area extending by $\pm 0.5^{\circ}$ around them as well as for the specific season when they were contacted regardless the year of measurements (e.g. a measurement performed in August is representative for the summer).

the absolute difference of $\mathrm{VCD}_{\mathrm{CHO}} \mathrm{CHO}$ for the period 2003 to 2007 has been calculated (Fig. 5b). The calculated detection limit for the average annual changes is about $2.5 \times 10^{13}$ molec $\mathrm{cm}^{-2} \mathrm{y}^{-1}$ based on the monthly value $\left(2 \times 10^{14}\right.$ molecules $\left.\mathrm{cm}^{-2}\right)$ and the reduction due to the temporal $\left(\sqrt{\left(\frac{1}{12}\right)}\right)$ and spatial $\left(\sqrt{\left(\frac{1}{4}\right)}\right)$ averaging used.
Above East Asia and mainly China, the calculated difference of the $\mathrm{VCD}_{\mathrm{CHO}} \mathrm{CHO}$ for the years 2003 to 2007 shows a significant increase (up to $3 \times 10^{14}$ molec $\mathrm{cm}^{-2}$ ) as depicted by the red color (Fig. 5b). The linear regression applied to the yearly-based data revealed an annual increase up to $5 \times 10^{13}$ molec $\mathrm{cm}^{-2} \mathrm{y}^{-1}$ (Fig. 5a). This increase is found in the same region where an increase in the tropospheric $\mathrm{NO}_{2}$ column amounts was observed during the period 1996-2004 

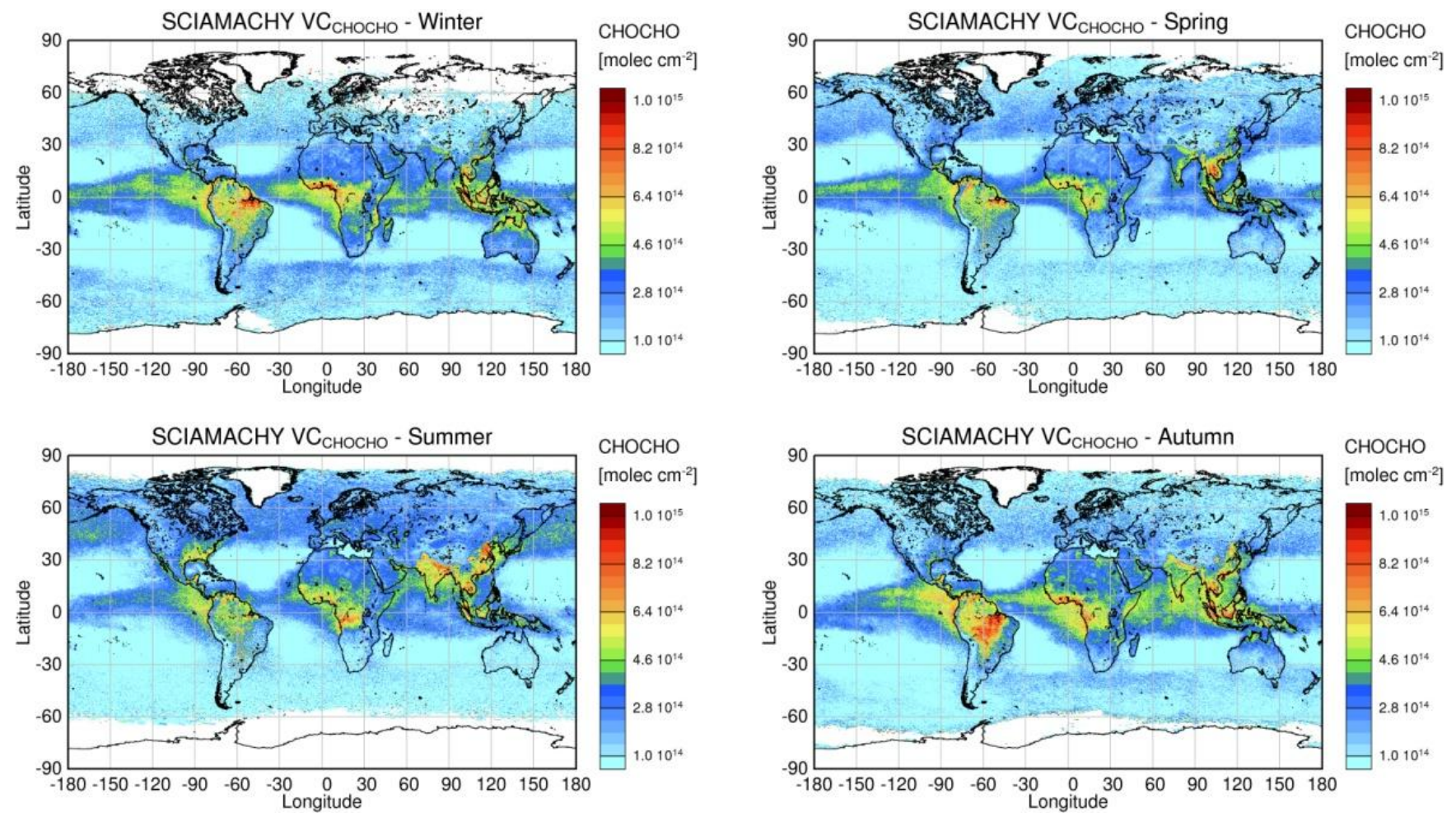

Fig. 6a. Seasonal variation of glyoxal: Seasonal means of CHO.CHO VCDs for December, January, and February (DJF), March, April, and May (MAM), June, July, August, (JJA) and September, October, November, (SON).

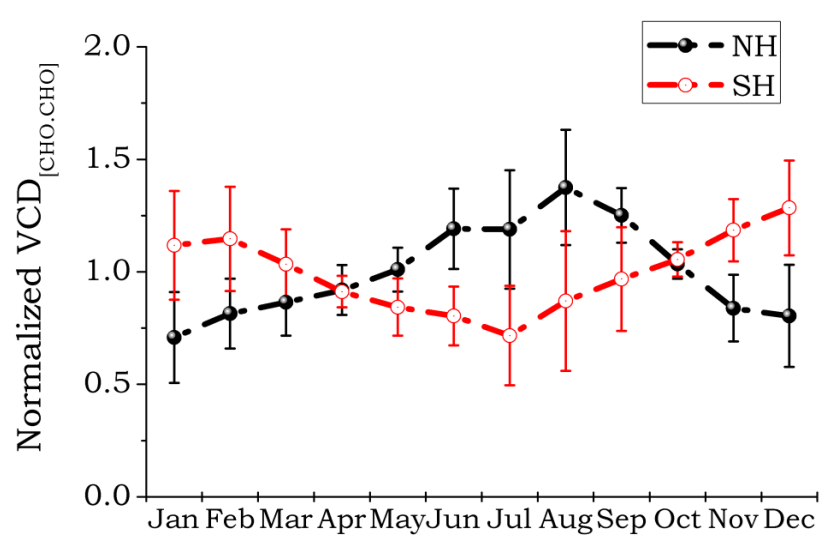

Fig. 6b. Mean normalized CHO.CHO VCDs calculated for the hot spots located in both NH (black dotted line) and SH (red dotted line) and described in Table 2.

over the same region (Richter et al., 2005) and which is still increasing. This implies that either an increase in the anthropogenic VOC precursors of glyoxal has occurred or there is a potential unknown direct emission of CHO.CHO, most likely originating from anthropogenic activities.

There are other places where the column amounts of glyoxal increase or decrease to a significant extent but less than in China. For example a local decrease of CHO.CHO $\left(\sim 3 \times 10^{13}\right.$ molec $\left.\mathrm{cm}^{-2} \mathrm{y}^{-1}\right)$ is found over the tropical forests of Congo at Central Africa. As the length of the data set is increasing, our knowledge of the significance of the local and regional changes in $\mathrm{CHO}$. $\mathrm{CHO}$ column will improve.

\subsection{Seasonal variability of glyoxal Vertical Column Densities}

The monthly seasonal mean values of the $\mathrm{VCD}_{\mathrm{CHO}}$.CHO data set are presented in Fig. 6a. As illustrated in these maps, CHO.CHO VCDs vary according to season. For the majority of the continental areas of both hemispheres, the highest amounts of glyoxal are observed during their respective summer and the lowest during winter. In general this behaviour can be explained by 1) enhanced biogenic emissions during the warm periods (Guenther et al., 2006) 2) enhanced amounts of oxidants during summer (Rohrer and Berresheim, 2006; Vrekoussis et al., 2004, 2007; Myriokefalitakis et al., 2008) and 3) overall an increase in the rate of oxidation of the emitted VOCs. The latter reflects, once more, the photochemical origin of $\mathrm{CHO}$. CHO. The pyrogenic emissions of VOC and CHO.CHO also contribute significantly to the observed seasonality as noted in the case of Africa, Amazonia and Indonesia.

In order to better illustrate the general pattern of the seasonal changes observed in the $\mathrm{NH}$ and the $\mathrm{SH}$, the 
Table 2. Median values of VCDs of CHO.CHO and HCHO coupled with their median ratio $\left(R_{G F}\right)$, the average EVI and the sum of fire numbers for the period 2003-2007. Data gridded to $0.5 \times 0.5^{\circ}$ have been used for the following analysis.

\begin{tabular}{|c|c|c|c|c|c|c|c|c|}
\hline & $\begin{array}{l}\text { Box number/ } \\
\text { Fig. } 8\end{array}$ & $\begin{array}{l}\text { Lat center } \\
{[\mathrm{deg}]}\end{array}$ & $\begin{array}{l}\text { Long center } \\
\text { [deg] }\end{array}$ & $\begin{array}{c}\text { CHO.CHO } \\
{\left[\text { molec } \mathrm{cm}^{-2}\right]}\end{array}$ & $\begin{array}{c}\mathrm{HCHO} \\
{\left[\mathrm{molec}^{-2}\right]}\end{array}$ & $R_{G F}$ & EVI & $\begin{array}{l}\text { Sum of Fire } \\
\text { counts }\end{array}$ \\
\hline N. America & $1-a$ & $32 \pm 4$ & $-90 \pm 10$ & $3.67 \times 10^{14}$ & $8.07 \times 10^{15}$ & 0.045 & 0.32 & 1061 \\
\hline S. America & $2-b$ & $0 \pm 10$ & $-62 \pm 8$ & $5.32 \times 10^{14}$ & $1.25 \times 10^{16}$ & 0.043 & 0.49 & 23759 \\
\hline S. America ${ }^{a}$ & 3-c & $-2 \pm 4$ & $-50 \pm 3$ & $6.62 \times 10^{14}$ & $1.38 \times 10^{16}$ & 0.048 & 0.47 & 13198 \\
\hline Africa_N & 4-d & $6 \pm 4$ & $1 \pm 10$ & $5.83 \times 10^{14}$ & $1.14 \times 10^{16}$ & 0.051 & 0.42 & 11098 \\
\hline Africa_E & $5-e$ & $2 \pm 4$ & $19 \pm 9$ & $5.36 \times 10^{14}$ & $1.29 \times 10^{16}$ & 0.042 & 0.46 & 3902 \\
\hline Africa_S & $6-f$ & $-7 \pm 5$ & $19 \pm 9$ & $5.05 \times 10^{14}$ & $1.10 \times 10^{15}$ & 0.046 & 0.39 & 2879 \\
\hline Indonesia & $7-\mathrm{i}$ & $2 \pm 6$ & $108 \pm 12$ & $5.54 \times 10^{14}$ & $8.34 \times 10^{15}$ & 0.066 & 0.43 & 22770 \\
\hline Australia & $8-1$ & $-14 \pm 3$ & $135 \pm 10$ & $3.75 \times 10^{14}$ & $6.09 \times 10^{15}$ & 0.062 & 0.24 & 21449 \\
\hline Asia_S & $9-\mathrm{k}$ & $25 \pm 3$ & $112 \pm 5$ & $5.79 \times 10^{14}$ & $1.25 \times 10^{16}$ & 0.046 & 0.35 & 1778 \\
\hline Asia_N & $10-j$ & $34 \pm 5$ & $116 \pm 5$ & $4.52 \times 10^{14}$ & $1.19 \times 10^{16}$ & 0.038 & 0.29 & 8057 \\
\hline India & $11-\mathrm{h}$ & $24 \pm 4$ & $85 \pm 7$ & $4.88 \times 10^{14}$ & $9.14 \times 10^{15}$ & 0.053 & 0.30 & 2535 \\
\hline Europe & $12-\mathrm{g}$ & $48 \pm 5$ & $7 \pm 6$ & $2.20 \times 10^{14}$ & $7.32 \times 10^{15}$ & 0.034 & 0.34 & 2127 \\
\hline
\end{tabular}

${ }^{\text {a }}$ SA box 3 is studied due to its higher glyoxal values in comparison to box 2 (details provided at Sect. 3.5.2)

"normalized" VCD $\mathrm{CHO}$.CHO have been calculated for selected hot spot areas $(1,4,9,10,11$ and 12 for the $\mathrm{NH}$ and 2, 3, 6, 7 and 8 for the $\mathrm{SH}$ ) depicted in Fig. 7 and presented in detail in the next section. The normalized $\mathrm{VCD}_{\mathrm{CHO}} \mathrm{CHO}$ values are derived from the monthly averages through division by the annual mean value, e.g. the normalized $\mathrm{VDC}_{\mathrm{CHO} . \mathrm{CHO}}$ for January is calculated from Eq. (1)

normalized $\operatorname{VCD}_{(\mathrm{Jan})}=\frac{\sum_{i}^{j}\left\{\mathrm{VCD}_{(\mathrm{Jan})} / \overline{N_{i}}\right\}}{(j-i+1)}$

In this equation, $i$ is the initial year of measurements, $j$ the end year, and $\overline{N_{i}}$ the annual average. The use of the normalized values reduces the month-to-month variability caused by the variation in the sources contributing to glyoxal production, e.g. an unexpected intensive biomass burning event.

The results of these calculations (Fig. 6b) confirms the above finding, that the CHO.CHO column amount has a strong seasonal variation with the highest values observed during the warm periods namely June to September for the $\mathrm{NH}$ (black circles) and November to February for the $\mathrm{SH}$ (Red empty circles). Depending on the sources and the differences in temperatures, the amplitude of those patterns may vary significantly (see Sect. 3.5 ).

\subsection{Photochemical "hot-spot" areas of VCD $\mathrm{CHO}_{\mathrm{CHO}}-$ seasonal variability}

After focusing on the global composite map of glyoxal column amount and its normalized seasonality, the next objective addresses selected specific areas of interest where the highest values of CHO.CHO columns are observed.

To perform this analysis, twelve "hot-spot" locations (Fig. 7a, black boxes) were selected. These locations are presented in Table 2 together with the median VCDs computed for $\mathrm{CHO} . \mathrm{CHO}$ and $\mathrm{HCHO}$, the average Enhanced Vegetation Index (EVI) (http://earthobservatory.nasa.gov/Observatory/) and the sum of the fire counts based on the analysis of the Advanced Along Track Scanning Radiometer, AATSR instrument (ATSR World Fire Atlas, http://dup.esrin.esa.int/ionia/ wfa/index.asp). It should be noted that all the datasets were gridded to the same resolution $\left(0.5^{\circ} \times 0.5^{\circ}\right)$. The respective results are discussed by region in the following subsections in conjunction with both their local seasonality and their interannual variability.

\subsubsection{North America}

The highest mean values of the VCDs of glyoxal over North America, NA, are observed above the Southern East Coast. This region, which is known to have a large biogenic emission, is characterized by enhanced EVI values, which is directly related to the photosynthetic capacity and primary productivity of the plant canopies.

Over the region defined as NA (Fig. 7 - box 1) the $\mathrm{VCD}_{\mathrm{CHO}} \mathrm{CHO}$ have a median annual value equal to $3.7 \times 10^{14}$ molec $\mathrm{cm}^{-2}$ which on average vary between low values in winter $\left(2.5 \times 10^{14}\right.$ molec $\left.\mathrm{cm}^{-2}\right)$ up to about $5.0 \times 10^{14}$ molec $\mathrm{cm}^{-2}$ in summer following the changes of the EVI (green line). The seasonal behaviour of the CHO.CHO values, as already pointed out, can be attributed to the oxidation of biogenic VOCs (bVOCs) such as isoprene (Wiedinmeyer et al., 2005) and terpenes. The oxidation of VOCs will lead also to high values of the column amount of $\mathrm{HCHO}$, which is a major product of the oxidation scheme of isoprene (Spaulding et al., 2003, and references therein).

Indeed and in agreement with the above assumptions, both the terrestrial isoprene emissions (Guenther et al., 2006) and 


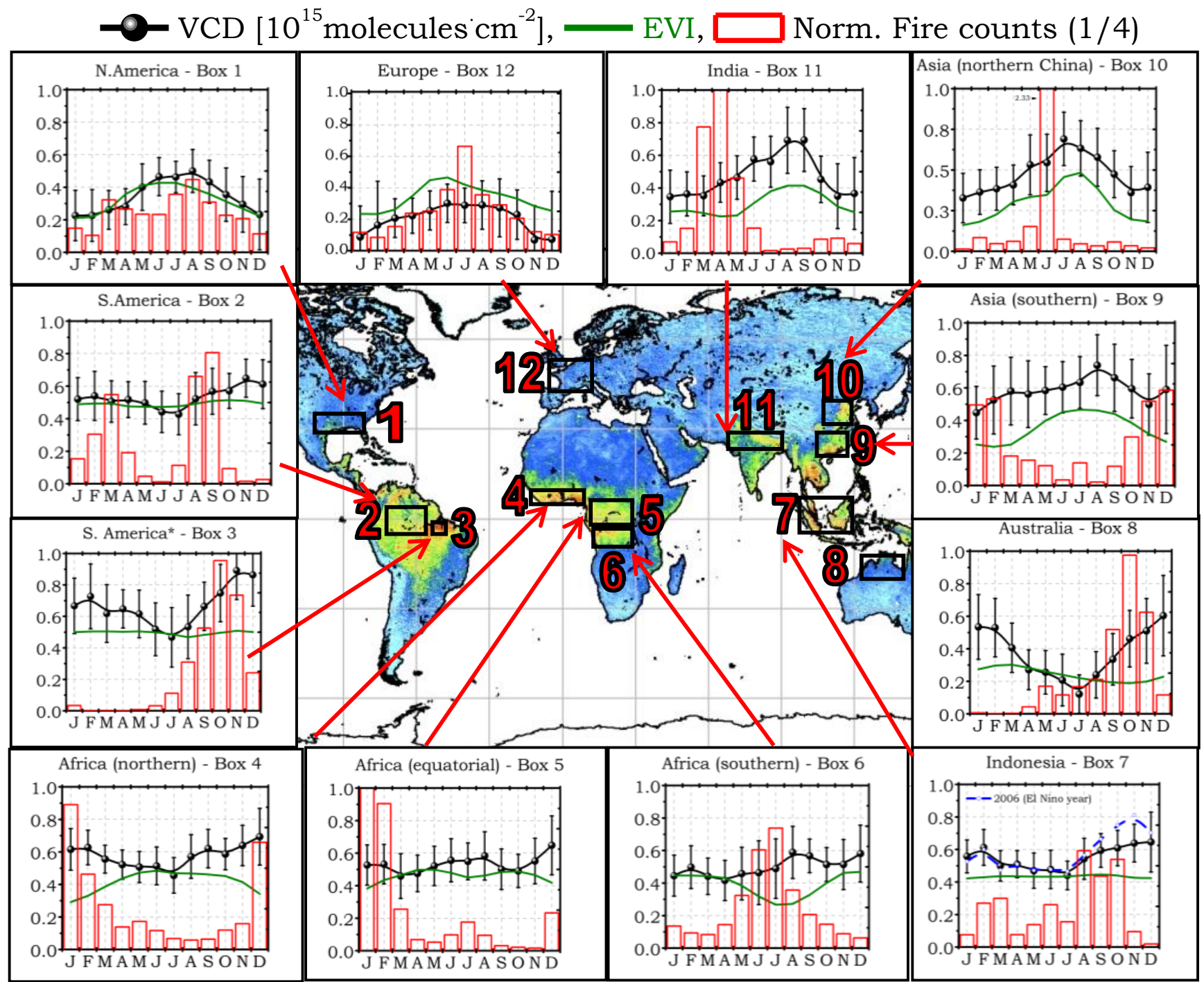

Fig. 7. Monthly mean variability of the $\mathrm{VCD}_{\mathrm{CHO}}$. CHO (black dotted line) computed over the 12 selected photochemical hotspots of Table 2 . The green line illustrates the Enhanced Vegetation Index calculated from MODIS data and the red columns depict the one fourth of the normalized, per year, fire counts as computed from the AATSR instrument.

the respective $\mathrm{VCD}_{\mathrm{HCHO}}$ observations (Chance et al., 2000; Abbot et al., 2003; Wittrock, 2006; De Smedt et al., 2008; Stavrakou et al., 2009a) show enhanced values above the Southern East Coast. The ratio $0.044 \pm 0.009$ computed from the annual mean values of $\mathrm{VCD}_{\mathrm{CHO} . \mathrm{CHO}} / \mathrm{VCD}_{\mathrm{HCHO}}$, defined as $R_{G F}$, agrees with the mean value of 0.045 found during the SCAPE experiment (Munger et al., 1995) held at the mountain ridge site in Shenandoah National Park, Virginia. Please note that in order to provide additional statistics, Table 2 presents the median $R_{G F}$ values.

Several other spots with high glyoxal values are revealed when looking across the NA continent. These are mainly influenced by anthropogenically emitted VOCs, e.g. above Los Angeles at the West Coast, where on average
$\mathrm{VCD}_{\mathrm{CHO} \text {.СHO }} \geq 5.8 \times 10^{14}$ molec $\mathrm{cm}^{-2}$ are found. The analysis of these more localized phenomena will be described in a forthcoming publication.

\subsubsection{South America}

As depicted in Fig. 7b, the highest $\mathrm{VCD}_{\mathrm{CHO}} \mathrm{CHO}$ are computed over the tropical rainforests of Amazonia. The abundance of CHO.CHO in this region is controlled not only by VOCs induced by biogenic sources (high values of EVI, Table 2) but also by biomass burning emission (Table 2). Although fires contribute less systematically than the biogenic emissions, their occurrence coincides with high amounts of glyoxal. This is confirmed from the analysis of the VCDs 
of CHO.CHO for boxes 2 (central and western SA) and 3 (eastern SA) presented in Fig. 7.

Here both the EVI and the calculated number of fires are high (Table 2). In addition, box 3 is a region where almost all fire events occur during the period July-October while box 2 encounters two fire seasons with the maxima of the fire counts observed in March and in September.

For the region 2, the median $\mathrm{VCD}_{\mathrm{CHO}} \mathrm{CHO}$ equals $5.3 \times 10^{14}$ molec $\mathrm{cm}^{-2}$. When focusing on the smaller box an increase of $25 \%$ is found in CHO.CHO. Interestingly the increase in $\mathrm{HCHO}$ is smaller (10\%) which implies that $\mathrm{CHO} . \mathrm{CHO}$, at least for this specific case study, might be a more sensitive metric for monitoring the air quality above biomass burning. The difference in the increase of the concentrations of those species results in slightly higher CHO.CHO/HCHO ratio of the mean VCDs ( $R_{G F}=0.049 \pm 0.016$ ) calculated for the small region in comparison to the respective one characterizing the larger region $\left(R_{G F}=0.045 \pm 0.012\right)$. The annual mean VCDs of $\mathrm{NO}_{2}$ remain quite low for both regions with the respective values being equal to $3-4 \times 10^{14}$ molec $\mathrm{cm}^{-2}$.

Interestingly, although the strength of the apparent sources of precursor VOCs linked to glyoxal production at both coherent regions are different, the seasonal variability (Fig. 7 boxes 2 and 3 ) is showing that the maxima are found during the same period around November and the minima around July.

For the larger area (box 2) this is supported by the findings of Huete et al. (2006), who observed a progressive increase of the EVI in Amazonia during the dry season (July-mid November). The same period coincides with the fire season affecting mainly the selected region 3 in addition to the impact of the local vegetation. The biomass burning in this case has a direct effect in the reported amplitude (Fig. 7, box 3) of the mean variability of $\mathrm{CHO}$. CHO which in total is enhanced by $85 \%$.

\subsubsection{Africa}

Africa is one of the continents where some of the highest glyoxal VCDs are observed. The reason is that as in the case of S. America, Central Africa is covered with dense vegetation, which have large emission of VOC and in addition biomass burning is a regular reoccurring phenomena. To the north and south of the tropical forests, the vegetation type changes to deciduous forests and savannas. In addition to these strong biogenic emissions, CHO.CHO is produced from wild fires and savannan fires (Cahoon et al., 1992). These fire events are seasonally dependant as it is shown not only from the ATSR world fire atlas but also from the respective carbon monoxide, $\mathrm{CO}$ from Mopitt (Measurements of pollution in the Troposphere, MOPITT, http://web.eos.ucar.edu/mopitt/index.html) and SCIAMACHY (Buchwitz et al., 2007). In West Africa fires peak from December to February and in Southern Africa during
May-August (Fig. 7, red columns). This results in different patterns in the observed seasonality as depicted in Fig. 7, in regional boxes 4 and 6 .

Moving from the Northern Hemisphere to the Southern Hemisphere for the selected regions in Fig. 7, a decrease in CHO.CHO amounts, is observed. The median VCD values are 5.8, 5.4 and $5.1 \times 10^{14}$ molec $\mathrm{cm}^{-2}$ for the boxed areas 4 , 5 and 6 respectively. Each of the three regions is controlled by different types and mixtures of emissions.

The 4th box, at the north west of the major tropical forest area is populated mostly with deciduous humid forests, derived Savanna and partially with tropical forests at its coastal borders to the south. The total amount of biomass burned in this region is the largest for the entire continent (Hao and Liu, 1994). Climatologically, there is a well distinguished "wet - dry" system characterizing this area. Glyoxal VCDs obtain their highest values (Fig. 7 - box 4) from December to February when the peak of fires is observed. An increase is observed from July. This behaviour can be explained by the high EVI values, implying large biogenic emissions and the ensuing photochemistry during summer. The computed ratio $R_{G F}$ is equal to $0.050 \pm 0.006$.

Box 5 is covered completely by tropical forest with wild fires occurring sporadically. The climate is tropical with fairly constant temperatures (around $27^{\circ} \mathrm{C}$ ) corresponding to two dry and two wet season (Stavrakou et al., 2009a). Small changes are found for the month-to-month variability of CHO.CHO and the $R_{G F}$ was $0.043 \pm 0.004$, a value close to the one already calculated over the biogenically influenced areas.

Finally, box 6 is covered by mid sub-humid wooden savannas and the climate is similar to the one mentioned for region 4 . The observed contrary seasonality is linked to the pyrogenic emissions occurring during the dry season which in this case peaks in August. The retrieved CHO.CHO has a two maxima shape with the highest values computed in $\mathrm{Au}-$ gust due to the fires, and the second in December due to the enhanced biogenic emissions. The $R_{G F}$ is in this case equal to $0.046 \pm 0.004$ slightly higher than the one of box 5 .

\subsubsection{Europe}

Over Europe the values of the glyoxal columns are moderate. Above the selected areas in Western Europe the anthropogenic sources are of major importance as expressed by the high $\mathrm{NO}_{2}$ vertical columns (Richter et al., 2005). The monthly mean CHO.CHO columns range from $1.5 \times 10^{14}$ molec cm $\mathrm{cm}^{-2}$ in winter to $3.0 \times 10^{14} \mathrm{molec} \mathrm{cm}^{-2}$ in summer (Fig. 7 - box 12) and the median annual value is $2.2 \times 10^{14}$ molec $\mathrm{cm}^{-2}$. The respective HCHO columns over the same region are also moderate and their median value is found to be equal to $7.3 \times 10^{15}$ molec $\mathrm{cm}^{-2}$. The ratio of both trace gases in this case is $R_{G F}=0.035 \pm 0.007$ suggesting that over anthropogenically influenced regions the ratio decreases as a result of higher primary sources of $\mathrm{HCHO}$ in comparison 
to the CHO.CHO ones (Garcia et al., 2006). Another indirect source of $\mathrm{HCHO}$ but not of CHO.CHO comes from the decomposition of the peroxyacetyl nitrate (PAN), a product of the photochemical reaction of VOCs and $\mathrm{NO}_{2}$. The thermal decomposition of PAN has a relatively large enthalpy resulting in a strong temperature dependence. PAN is therefore a temporary reservoir for $\mathrm{HCHO}$.

\subsubsection{Asia}

Four hot spots are selected over Asia. One is found over India, one in Indonesia and two over China.

Both the southern and northern China regions (Fig. 7 - boxes 9 and 10) are controlled by strong biogenic as well as pyrogenic emissions (Fu et al., 2007; Stavrakou et al., 2009a). The northern region is additionally fingerprinted by agricultural biomass burning which maximizes in June (Fu et al., 2007) and with rapidly increasing anthropogenic emissions (Richter et al., 2005). The median annual value of the $\mathrm{VCD}_{\mathrm{CHO}}$.CHO is higher for the southern box $\left(5.8 \times 10^{14} \mathrm{molec}^{-2}\right)$ in comparison to the northern $\left(4.5 \times 10^{14}\right.$ molec cm $\left.^{-2}\right)$.

The seasonal pattern is relatively similar for both areas, with the maximum values being retrieved during summer but a second increase found in March until July for the southern region. This increase has been observed also in the HCHO values (Fu et al., 2007; Stavrakou et al., 2009a). The calculated $R_{G F}$ s are $0.046 \pm 0.005$ and $0.039 \pm 0.005$ for the southern and the northern boxes respectively. The values of the median $\mathrm{VCD}_{\mathrm{NO} 2}$ were almost 5 times larger over the northern China suggesting, as in the case of Europe, that the lowest values of $R_{G F}$ occur over areas where anthropogenically induced emissions from fossil fuel combustion occur.

In India the selected hot spot is located above a densely populated area (http://earthobservatory.nasa.gov/IOTD/view. php?id=432) close to the Himalaya Mountains. The seasonality of glyoxal follows the northern hemispheric pattern with the maxima found in summer (Fig. 7 - box 11). The median annual value was equal to $4.9 \times 10^{14} \mathrm{molec}^{-2}$ and the computed $R_{G F}$ was $0.053 \pm 0.008$. These numbers point to the existence of supplementary sources of CHO.CHO in addition to the biogenic emissions occurrence. Another major source of NMVOCs in India are the residential emissions (wood fuel), as reported in the Emission Database for Global Atmospheric Research (EDGAR). The relatively low median $\mathrm{NO}_{2}$ VCDs $\left(2.5 \times 10^{15}\right.$ molec cm $\left.\mathrm{cm}^{-2}\right)$ over box 11 agrees with the findings of the EDGAR database stating that the pollution induced from industrialization processes currently is not the key contributor to NMVOC production.

Over Indonesia (Fig. 7 - box 7), the annual cycle in glyoxal is not so pronounced. Higher mean VCDs are observed from September to February and lower columns from March to August. The median $\mathrm{VCD}_{\mathrm{CHO}}$.сHO was $5.5 \times 10^{14}$ molec $\mathrm{cm}^{-2}$ and the reported $R_{G F}$ of $0.068 \pm 0.039$ was not only the highest among all the studied values of the
12 hot spots but also the one with the greatest variability. At first glance, this appears to be linked with increased biomass burning, which can be supported by the conditions occurring in this region. Indonesia is covered by tropical forests. Climatologically, it is affected by a dry monsoonal period mainly between July and October. During this period, fires are started for agricultural land clearing and deforestation. In parallel, wild fires occur at the tropical forests due to the dry climate (Murdiyarso and Adiningsih, 2006). Changing from rain forest to commercial crops is also changing the type and pattern of emissions of VOC. In addition Indonesia is one of the regions suffering from the drier conditions caused by the El-Niño phenomenon and subsequently the increase of fire numbers. As seen in Fig. 7 - box 7 (blue dashed line),

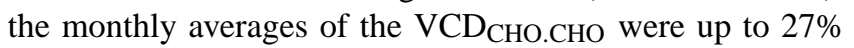
higher in 2006, a characteristic El-Niño year, in comparison to the data excluding the El-Nino year (not shown here), during October and November.

\subsubsection{Australia}

Northern Australia is also characterised by biogenic emissions and periods of biomass burning. Both contribute to the observed seasonal cycle, which minimizes during the cold period (JJA) due to the absence of precursors in addition to lower photochemistry. During the fire season (JulyDecember) glyoxal columns exhibit a sharp increase 4$5 \times 10^{14}$ molecules $\mathrm{cm}^{-2}$, which ends in February when the maximum EVI values are obtained (Fig. 7 - box 8 ). The observed ratio of $\mathrm{CHO} . \mathrm{CHO}$ to $\mathrm{HCHO}$ is $0.059 \pm 0.009$ indicative of the large numbers of fires in addition to the biogenic emissions occurring in Northern Australia.

\subsubsection{Oceanic VCD $\mathrm{CHO}_{\mathrm{CHO}}$}

The retrieved trace-gas observations of small absorbers suffer from different potential error sources over water (e.g. interference from liquid water absorption and vibrational Raman infilling of Fraunhofer line) than over land. This makes their interpretation more demanding in comparison to land values. However assuming that the retrieved $\mathrm{SCD}_{\mathrm{CHO} \text {.CHO }}$ and $\mathrm{VCD}_{\mathrm{CHO}}$.СHO are accurate within error this results to the following analysis.

High $\mathrm{VCD}_{\mathrm{CHO} \text {.CHO }}$ (in some cases $\geq 4 \times 10^{4}$ molec $^{-2}$ ) are observed at several regions above the ocean (Fig. 2c). The most abundant oceanic regions of glyoxal are in the tropics. In addition there is a seasonal modulation of CHO.CHO over the southern oceans and northern ocean. The values of CHO.CHO are less over the higher latitudes but a clear seasonal cycle is observed. These regions where CHO.CHO is found above the oceans are known to be biological active: relatively large amounts of phytoplankton monitored from space result to enhanced Oceanic Net Primary Productivity values (npp, http://www.science.oregonstate.edu/ocean. 


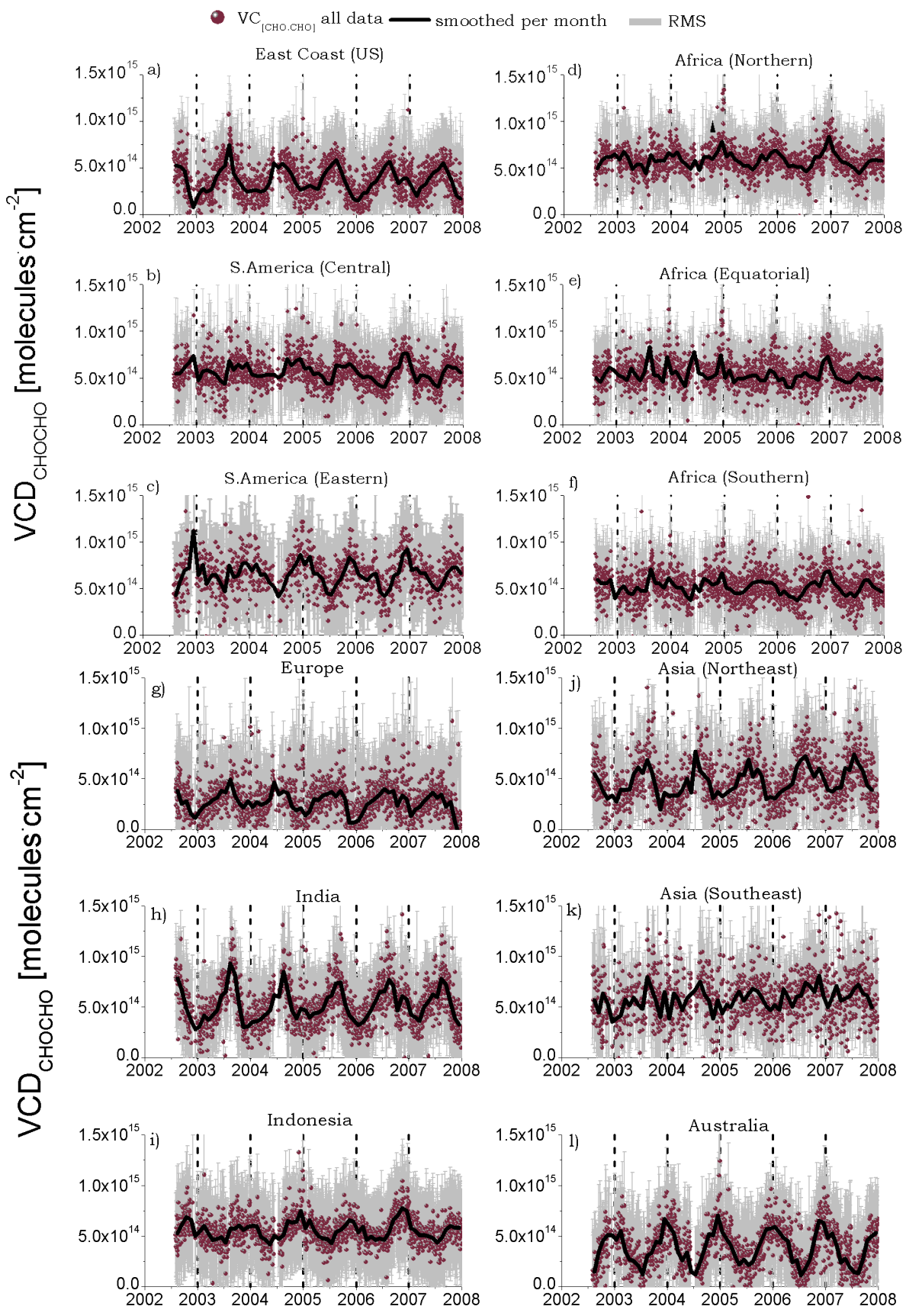

Fig. 8. Interannual variability of the vertical column densities of glyoxal over the selected hotspots. The dots show all the individual measurements, the black lines present the respective monthly means and the gray lines corresponds to the residual mean squares (RMS) of the fit for each individual measurement.

productivity/, based on MODIS chlorophyll and temperature data).

The strong signals in the tropics in particular in the Pacific are affected by the Intertropical Convergence Zone (ITCZ). In this region strong convection occurs lifting moistair masses having marine aerosol.
The latter is indicative of another potential source of the glyoxal over oceans: the convection of organic aerosols, rich in dissolved organic carbon (DOC) to the troposphere. The oceanic and coastal surface microlayers are enriched in low molecular weight carbonyls in comparison to the subsurface water as a result of the enhanced photo-production rate (Zhou and Mopper, 1997). This may facilitate their release to the 




Fig. 9. Linear regression analysis of the CHO.CHO VCDs coupled with their uncertainties $(2 \sigma)$, over the selected hotspots of Table 2 . The red columns show the annual increase of the VCDs of glyoxal observed over Northeastern Asia.

atmosphere at the surface or from marine aerosol, which is created from wave breaking and foam etc. The surface layer of the ocean and these aerosols under the presence of oxidants $\left(\mathrm{OH}, \mathrm{O}_{3}\right.$ and $\left.\mathrm{NO}_{3}\right)$ and/or halogens may result in the dissolved organic carbon being oxidized and organic compounds and radicals being released to the gas phase. Possibly a complex process controls the chemical scheme of the production of CHO.CHO from the oceanic sources and further investigation is needed.

The oceanic behavour of CHO.CHO in connection with various oxidants (e.g. $\mathrm{O}_{3}, \mathrm{OH}, \mathrm{IO}$ ) as well as with the observed net primary productivity is subject of a paper in preparation.

\subsection{Interannual variability and trends over the hotspot areas}

The hot-spots described above are now analyzed in terms of their interannual variability. The individual measurements of $\mathrm{VCD}_{\mathrm{CHO}}$.сHо coupled with the respective residual mean squares (RMS) and the monthly means are illustrated in Fig. 8.

The seasonal patterns emanating from this figure were already described above. In order to observe potential trends for the specific selected hot spots of glyoxal, a linear regression analysis has been applied to the results and the outcome is presented separately in Fig. 9.

Four of the twelve hot-spots, NE and SE Asia, India and Australia present an annual increase in CHO.CHO Vertical Column Densities. For Australia, India and SE Asia the annual computed increase of $1.6 \%$ and $1.2 \%$ and $3.5 \%$, respectively, is small. Notably, during the period 2003-2007, the vertical columns of glyoxal increased over NE China by about $45 \%$. This increase is attributed, at least partially to the increase of the VOC emissions following the rapid and continuous economic development of this region (Richter et al., 2005).

On the contrary, a small decrease of $4.0 \%, 1.3 \%, 1.7 \%$, $4 \%$, and $3 \%$ in the $\mathrm{VCD}_{\mathrm{CHO}}$.CHO was found over Western Europe, S. America, and Africa respectively. Over Western Europe, a 18\% $\mathrm{NO}_{\mathrm{x}}$ emission reduction, from 1996 to 2002, is also reported (Richter et al., 2005). This reduction in $\mathrm{NO}_{\mathrm{x}}$ emissions reflects the decrease of man-made emissions. The decrease of glyoxal has to be treated with care as the median value of the $\mathrm{VCD}_{\mathrm{CHO} \text {.CHO }}$ for the studied period is also very low $\left(2.2 \times 10^{14}\right.$ molecules $\left.\mathrm{cm}^{-2}\right)$.

As the length of the data set increases, the significance of the observed changes and any non linear behaviour will become clearer.

\section{Conclusions}

SCIAMACHY measurements of the upwelling radiance at the top of the atmosphere have been used to obtain the first global multi-annual (2002-2007) dataset of the glyoxal vertical column densities. The slant columns were retrieved in the $435-457 \mathrm{~nm}$ spectral region using the DOAS technique: slant column densities being initially retrieved and then converted to vertical columns densities by using air mass factors. The verification and validation of the space-based observations was made using ground-based measurements reported in the literature. Taking into account the assumptions needed to obtain a coherent dataset, the comparisons between ground 
based and satellite data showed a good agreement within uncertainties.

As glyoxal's lifetime is short (about $2-3 \mathrm{~h}$ ), the column amounts of CHO.CHO can be used as a regional and global marker of photochemical hot-spots, which are defined as regions where photochemical oxidation of chemical species is rapid. Several hot-spots regions were selected and their temporal variation was analyzed. Spatially, the highest values of glyoxal VCDs are observed over tropical and sub-tropical regions. South America, Africa, India, Indonesia and Asia (mainly China) have the largest columns of CHO.CHO followed by North America ground scenes, Europe and Australia. Notably, large column amounts of glyoxal are also found above the ocean, close to upwelling areas and above regions having large concentrations of phytoplankton suggesting biogenic activity, perhaps coupled with photochemistry as the oceanic source of the CHO.CHO.

The highest glyoxal amounts are found over regions controlled by strong biogenic and pyrogenic emissions. The VOCs emitted from those sources act as the precursor "fuel" in the CHO.CHO production. Nevertheless attention should be given to exploit the primary emission of glyoxal, linked to the strong biomass burning events.

Temporally, the levels of glyoxal vary seasonally due to the changes in the biogenically emitted VOCs, mainly isoprene and the ones originating from man-made fires. Other important factors controlling the seasonality of $\mathrm{CHO}$. $\mathrm{HO}$ are the oxidant levels and the induced photochemical reactions. In general, the highest values of the $\mathrm{VCD}_{\mathrm{CHO}}$.CHO are observed for both hemispheres during summer and the lowest during winter.

The reported ratio of the $\mathrm{CHO}$. $\mathrm{CHO}$ to $\mathrm{HCHO}$ amounts was found to be about 0.045 over the source regions controlled by biogenic sources. When shifting to regions affected additionally by biomass burning an increase of this ratio has been computed. On the contrary the presence of anthropogenic sources has been connected to a decrease of the respective ratio possibly due to the additional sources of HCHO. Further temporal and spatial investigation is needed to better characterize this ratio.

Finally, the interannual global analysis showed that over Northeastern China, an increase in glyoxal column amounts of about $3.5 \times 10^{13}$ molec $\mathrm{cm}^{-2} \mathrm{y}^{-1}$ or else of $45 \%$ is found for the period 2003 to 2007 .

Acknowledgements. Mihalis Vrekoussis acknowledges the A. v. Humboldt foundation and the European Union (Marie Curie) for the consecutive research fellowships. We appreciate the provision of MODIS data via the internet by NASA/GSFC and ATSR World Fire Atlas. This work has in part been funded by the DLR, the State of of Bremen, and the EU ACCENT Project. The UB thanks the ESA and DLR for the provision of level 0 and level 1 data from SCIAMACHY.

Edited by: B. N. Duncan

\section{References}

Abbot, D. S., Palmer, P. I., Martin, R. V., Chance, K. V., Jacob, D. J., and Guenther, A.: Seasonal and interannual variability of North American isoprene emissions as determined by formaldehyde column measurements from space, Geophys. Res. Lett., 30(17), 1886, doi:10.1029/2003g1017336, 2003.

Bloss, C., Wagner, V., Jenkin, M. E., Volkamer, R., Bloss, W. J., Lee, J. D., Heard, D. E., Wirtz, K., Martin-Reviejo, M., Rea, G., Wenger, J. C., and Pilling, M. J.: Development of a detailed chemical mechanism (MCMv3.1) for the atmospheric oxidation of aromatic hydrocarbons, Atmos. Chem. Phys., 5, 641-664, 2005, http://www.atmos-chem-phys.net/5/641/2005/.

Bogumil, K., Orphal, J., Homann, T., Voigt, S., Spietz, P., Fleischmann, O. C., Vogel, A., Hartmann, M., Kromminga, H., Bovensmann, H., Frerick, J., and Burrows, J. P.: Measurements of molecular absorption spectra with the SCIAMACHY pre-flight model: instrument characterization and reference data for atmospheric remote-sensing in the $230-2380 \mathrm{~nm}$ region, J. Photochem. Photobiol. a-Chemistry, 157, 167-184, doi:10.1016/S1010-6030(03)00062-5, 2003.

Bovensmann, H., Burrows, J. P., Buchwitz, M., Frerick, J., Noel, S., Rozanov, V. V., Chance, K. V., and Goede, A. P. H.: SCIAMACHY: Mission objectives and measurement modes, J. Atmos. Sci., 56, 127-150, 1999.

Bracher, A. U. and Tilzer, M. M.: Underwater light field and phytoplankton absorbance in different surface water masses of the Atlantic sector of the Southern Ocean, Polar Biology, 24, 687696, 2001.

Buchwitz, M., Khlystova, I., Bovensmann, H., and Burrows, J. P.: Three years of global carbon monoxide from SCIAMACHY: comparison with MOPITT and first results related to the detection of enhanced CO over cities, Atmos. Chem. Phys., 7, 23992411, 2007, http://www.atmos-chem-phys.net/7/2399/2007/.

Burrows, J. P., Holzle, E., Goede, A. P. H., Visser, H., and Fricke, W.: Sciamachy - Scanning Imaging Absorption Spectrometer for Atmospheric Chartography, Acta Astronautica, 35, 445-451, 1995.

Cahoon, D. R., Stocks, B. J., Levine, J. S., Cofer, W. R., and Oneill, K. P.: Seasonal Distribution of African Savanna Fires, Nature, 359, 812-815, 1992.

Calvert, J. G., Atkinson, R., Kerr, J. A., Madronich, S., Moortgat, G. K., Wallington, T. J., and Yarwood, G.: The Mechanisms of Atmospheric Oxidation of the Alkenes, Oxford University Press, New York, 2000.

Calvert, J. G., Atkinson, R., Becker, K. H., Kamens, R. M., Seinfeld, J. H., Wallington, T. J., and Yarwood, G.: The Mechanisms of Atmospheric Oxidation of Aromatic Hydrocarbons, Oxford University Press, Oxford, 2002.

Cerqueira, M. A., Pio, C. A., Gomes, P. A., Matos, J. S., and Nunes, T.: Volatile organic compounds in rural atmospheres of central Portugal, Sci. Total Environ., 313, 49-60, doi:10.1016/S00489697(03)00250-X, 2003.

Chance, K., Palmer, P. I., Spurr, R. J. D., Martin, R. V., Kurosu, T. P., and Jacob, D. J.: Satellite observations of formaldehyde over North America from GOME, Geophys. Res. Let., 27, 34613464, 2000.

De Smedt, I., Müller, J.-F., Stavrakou, T., van der A, R., Eskes, H., and Van Roozendael, M.: Twelve years of global observations of formaldehyde in the troposphere using GOME and SCIA- 
MACHY sensors, Atmos. Chem. Phys., 8, 4947-4963, 2008, http://www.atmos-chem-phys.net/8/4947/2008/.

Fu, T. M., Jacob, D. J., Wittrock, F., Burrows, J. P., Vrekoussis, M., and Henze, D. K.: Global budgets of atmospheric glyoxal and methylglyoxal, and implications for formation of secondary organic aerosols, J. Geophys. Res.-Atmos., 113, D15303, doi:10.1029/2007jd009505, 2008.

Garcia, A. R., Volkamer, R., Molina, L. T., Molina, M. J., Samuelson, J., Mellqvist, J., Galle, B., Herndon, S. C., and Kolb, C. E.: Separation of emitted and photochemical formaldehyde in Mexico City using a statistical analysis and a new pair of gas-phase tracers, Atmos. Chem. Phys., 6, 4545-4557, 2006, http://www.atmos-chem-phys.net/6/4545/2006/.

Gottwald, M., Bovensmann, H., Lichtenberg, G., Noel, S., von Bargen, A., Slijkhuis, S., Piters, A., Hoogeveen, R., von Savigny, C., Buchwitz, M., Kokhanovsky, A., Richter, A., Rozanov, A., Holzer-Popp, T., Bramstedt, K., Lambert, J.-C., Skupin, J., Wittrock, F., Schrijver, H., and Burrows, J. P.: SCIAMACHY, Monitoring the Changing Earth's Atmosphere, published by DLR, 2006.

Greenblatt, G. D., Orlando, J. J., Burkholder, J. B., and Ravishankara, A. R.: Absorption-Measurements of Oxygen between $330 \mathrm{~nm}$ and $1140 \mathrm{~nm}$, J. Geophys. Res.-Atmos., 95, 1857718582, 1990.

Grosjean, D., Grosjean, E., and Gertler, A. W.: On-road emissions of carbonyls from light-duty and heavy-duty vehicles, Environ. Sci. Technol., 35, 45-53, 2001.

Grosjean, E., Grosjean, D., Fraser, M. P., and Cass, G. R.: Air quality model evaluation data for organics .2. C-1-C-14 carbonyls in Los Angeles air, Environ. Sci. Technol., 30, 2687-2703, 1996.

Guenther, A., Karl, T., Harley, P., Wiedinmyer, C., Palmer, P. I., and Geron, C.: Estimates of global terrestrial isoprene emissions using MEGAN (Model of Emissions of Gases and Aerosols from Nature), Atmos. Chem. Phys., 6, 3181-3210, 2006, http://www.atmos-chem-phys.net/6/3181/2006/.

Hao, W. M. and Liu, M. H.: Spatial and Temporal Distribution of Tropical Biomass Burning, Global Biogeochem. Cycles, 8, 495503, 1994.

Hays, M. D., Geron, C. D., Linna, K. J., Smith, N. D., and Schauer, J. J.: Speciation of gas-phase and fine particle emissions from burning of foliar fuels, Environ. Sci. Technol., 36, 2281-2295, doi:10.1021/Es0111683, 2002.

Houweling, S., Dentener, F., and Lelieveld, J.: The impact of nonmethane hydrocarbon compounds on tropospheric photochemistry, J. Geophys. Res.-Atmos., 103, 10673-10696, 1998.

Huete, A. R., Didan, K., Shimabukuro, Y. E., Ratana, P., Saleska, S. R., Hutyra, L. R., Yang, W. Z., Nemani, R. R., and Myneni, R.: Amazon rainforests green-up with sunlight in dry season, Geophys. Res. Lett., 33, L06405, doi:10.1029/2005g1025583, 2006.

Ieda, T., Kitamori, Y., Mochida, M., Hirata, R., Hirano, T., Inukai, K., Fujinuma, Y., and Kawamura, K.: Diurnal variations and vertical gradients of biogenic volatile and semi-volatile organic compounds at the Tomakomai larch forest station in Japan, Tellus Series B-Chemical and Physical Meteorology, 58, 177-186, doi:10.1111/j.1600-0889.2006.00179.x, 2006.

Jing, L. H., Steinberg, S. M., and Johnson, B. J.: Aldehyde and monocyclic aromatic hydrocarbon mixing ratios at an urban site in Las Vegas, Nevada, J. Air Waste Manage. Assoc., 51, 1359$1366,2001$.
Kanakidou, M., Seinfeld, J. H., Pandis, S. N., Barnes, I., Dentener, F. J., Facchini, M. C., Van Dingenen, R., Ervens, B., Nenes, A., Nielsen, C. J., Swietlicki, E., Putaud, J. P., Balkanski, Y., Fuzzi, S., Horth, J., Moortgat, G. K., Winterhalter, R., Myhre, C. E. L., Tsigaridis, K., Vignati, E., Stephanou, E. G., and Wilson, J.: Organic aerosol and global climate modelling: a review, Atmos. Chem. Phys., 5, 1053-1123, 2005,

http://www.atmos-chem-phys.net/5/1053/2005/.

Kawamura, K., Steinberg, S., and Kaplan, I. R.: Homologous series of C-1-C-10 monocarboxylic acids and C-1-C-6 carbonyls in Los Angeles air and motor vehicle exhausts, Atmos. Environ., 34, 4175-4191, 2000.

Kean, A. J., Grosjean, E., Grosjean, D., and Harley, R. A.: Onroad measurement of carbonyls in California light-duty vehicle emissions, Environ. Sci. Technol., 35, 4198-4204, 2001.

Kroll, J. H., Ng, N. L., Murphy, S. M., Varutbangkul, V., Flagan, R. C., and Seinfeld, J. H.: Chamber studies of secondary organic aerosol growth by reactive uptake of simple carbonyl compounds, J. Geophys. Res.-Atmos., 110, D23207, doi:10.1029/2005jd006004, 2005.

Lee, Y. N., Zhou, X. L., and Hallock, K.: Atmospheric carbonyl compounds at a rural southeastern United States site, J. Geophys. Res.-Atmos., 100, 25933-25944, 1995.

Lee, Y. N., Zhou, X., Kleinman, L. I., Nunnermacker, L. J., Springston, S. R., Daum, P. H., Newman, L., Keigley, W. G., Holdren, M. W., Spicer, C. W., Young, V., Fu, B., Parrish, D. D., Holloway, J., Williams, J., Roberts, J. M., Ryerson, T. B., and Fehsenfeld, F. C.: Atmospheric chemistry and distribution of formaldehyde and several multioxygenated carbonyl compounds during the 1995 Nashville Middle Tennessee Ozone Study, J. Geophys. Res.-Atmos., 103, 22449-22462, 1998.

Liggio, J., Li, S. M., and Mclaren, R.: Heterogeneous reactions of glyoxal on particulate matter: Identification of acetals and sulfate esters, Environ. Sci. Technol., 39, 1532-1541, 2005a

Liggio, J., Li, S. M., and McLaren, R.: Reactive uptake of glyoxal by particulate matter. J. Geophys. Res., 110, D10304, doi:10310.11029/2004JD005113, 2005b.

Lim, H. J., Carlton, A. G., and Turpin, B. J.: Isoprene forms secondary organic aerosol through cloud processing: Model simulations, Environ. Sci. Technol., 39, 4441-4446, doi:10.1021/Es048039h, 2005.

Monks, P. S.: Gas-phase radical chemistry in the troposphere, Chemical Society Reviews, 34, 376-395, doi:10.1039/B307982c, 2005 .

Moortgat, G. K., Grossmann, D., Boddenberg, A., Dallmann, G., Ligon, A. P., Turner, W. V., Gab, S., Slemr, F., Wieprecht, W., Acher, K., Kilber, M., Schlomski, S., and Bachmann, K.: Hydrogen Peroxide, Organic Peroxides and Higher Carbonyl Compounds Determined during the BERLIOZ Campaign, J. Atmos. Chem., 42, 443-463, 2002.

Müller, K., van Pinxteren, D., Plewka, A., Svrcina, B., Kramberger, H., Hofmann, D., Bachmann, K., and Herrmann, H.: Aerosol characterisation at the FEBUKO upwind station Goldlauter (II): Detailed organic chemical characterisation, Atmos. Environ., 39, 4219-4231, doi:10.1016/j.atmosenv.2005.02.008, 2005.

Müller, J.-F., Stavrakou, T., Wallens, S., De Smedt, I., Van Roozendael, M., Potosnak, M. J., Rinne, J., Munger, B., Goldstein, A., and Guenther, A. B.: Global isoprene emissions estimated using MEGAN, ECMWF analyses and a detailed canopy environment 
model, Atmos. Chem. Phys., 8, 1329-1341, 2008,

http://www.atmos-chem-phys.net/8/1329/2008/.

Munger, J. W., Jacob, D. J., Daube, B. C., Horowitz, L. W., Keene, W. C., and Heikes, B. G.: Formaldehyde, Glyoxal, and Methylglyoxal in Air and Cloudwater at a Rural Mountain Site in Central Virginia, J. Geophys. Res.-Atmos., 100, 9325-9333, 1995.

Murdiyarso, D. and Adiningsih, E.: Climate anomalies, Indonesian vegetation fires and terrestrial carbon emissions, Mitigation and Adaptation Strategies for Global Change, 12(1), 101-112, doi:10.1007/s11027-006-9047-4, 2006.

Myriokefalitakis, S., Vrekoussis, M., Tsigaridis, K., Wittrock, F., Richter, A., Brühl, C., Volkamer, R., Burrows, J. P., and Kanakidou, M.: The influence of natural and anthropogenic secondary sources on the glyoxal global distribution, Atmos. Chem. Phys., 8, 4965-4981, 2008,

http://www.atmos-chem-phys.net/8/4965/2008/.

Palmer, P. I., Jacob, D. J., Fiore, A. M., Martin, R. V., Chance, K., and Kurosu, T. P.: Mapping isoprene emissions over North America using formaldehyde column observations from space, J. Geophys. Res.-Atmos., 108(D6), 4180, doi:10.1029/2002jd002153, 2003.

Palmer, P. I., Abbot, D. S., Fu, T. M., Jacob, D. J., Chance, K., Kurosu, T. P., Guenther, A., Wiedinmyer, C., Stanton, J. C., Pilling, M. J., Pressley, S. N., Lamb, B., and Sumner, A. L.: Quantifying the seasonal and interannual variability of North American isoprene emissions using satellite observations of the formaldehyde column, J. Geophys. Res.-Atmos., 111, D12315, doi:10.1029/2005jd006689, 2006.

Platt, U. and Perner, D.: Direct Measurements of Atmospheric Ch2o,Hno2,O3,No2, and So2 by Differential Optical-Absorption in the near Uv, J. Geophys. Res.-Oceans and Atmospheres, 85, 7453-7458, 1980.

Platt, U.: Differential optical absorption spectroscopy (DOAS), Air Monitoring by Spectroscopic Techniques, edited by: Sigrist, M. W., John Wiley \& Sons, Inc., New York, 127, 27-84, 1994.

Poisson, N., Kanakidou, M., and Crutzen, P. J.: Impact of nonmethane hydrocarbons on tropospheric chemistry and the oxidizing power of the global troposphere: 3-dimensional modelling results, J. Atmos. Chem., 36, 157-230, 2000.

Pope, C. A. and Dockery, D. W.: Health effects of fine particulate air pollution: Lines that connect, J. Air Waste Manage. Assoc., 56, 709-742, 2006.

Ramanathan, V. and Crutzen, P. J.: New directions: Atmospheric brown "Clouds", Atmos. Environ., 37, 4033-4035, doi:10.1016/S1352-2310(03)00536-3, 2003.

Richter, A. and Burrows, J. P.: Tropospheric $\mathrm{NO}_{2}$ from GOME Measurements, Adv. Space Res., 29(11), 1673-1683, 2001.

Richter, A., Burrows, J. P., Nuss, H., Granier, C., and Niemeier, U.: Increase in tropospheric nitrogen dioxide over China observed from space, Nature, 437, 129-132, doi:10.1038/Nature04092, 2005.

Roberts, G. C., Artaxo, P., Zhou, J. C., Swietlicki, E., and Andreae, M. O.: Sensitivity of CCN spectra on chemical and physical properties of aerosol: A case study from the Amazon Basin, J. Geophys. Res.-Atmos., 107(D20), 8070, doi:10.1029/2001jd000583, 2002.

Rohrer, F. and Berresheim, H.: Strong correlation between levels of tropospheric hydroxyl radicals and solar ultraviolet radiation, Nature, 442, 184-187, doi:10.1038/Nature04924, 2006.
Rozanov, A., Rozanov, V., Buchwitz, M., Kokhanovsky, A., and Burrows, J. P.: SCIATRAN 2.0 - A new radiative transfer model for geophysical applications in the $175-2400 \mathrm{~nm}$ spectral region, Atmospheric Remote Sensing: Earth's Surface, Troposphere, Stratosphere and Mesosphere - I, 36, 1015-1019, doi:10.1016/j.asr.2005.03.012, 2005.

Seaman, V. Y., Charles, M. J., and Cahill, T. M.: A sensitive method for the quantification of acrolein and other volatile carbonyls in ambient air, Analyt. Chem., 78, 2405-2412, doi:10.1021/Ac051947s, 2006.

Sinreich, R., Volkamer, R., Filsinger, F., Frieß, U., Kern, C., Platt, U., Sebastián, O., and Wagner, T.: MAX-DOAS detection of glyoxal during ICARTT 2004, Atmos. Chem. Phys., 7, 1293-1303, 2007, http://www.atmos-chem-phys.net/7/1293/2007/.

Spaulding, R. S., Schade, G. W., Goldstein, A. H., and Charles, M. J.: Characterization of secondary atmospheric photooxidation products: Evidence for biogenic and anthropogenic sources, J. Geophys. Res.-Atmos., 108(D8), 4247, doi:10.1029/2002jd002478, 2003.

Stavrakou, T., Müller, J.-F., De Smedt, I., Van Roozendael, M., van der Werf, G. R., Giglio, L., and Guenther, A.: Evaluating the performance of pyrogenic and biogenic emission inventories against one decade of space-based formaldehyde columns, Atmos. Chem. Phys., 9, 1037-1060, 2009a,

http://www.atmos-chem-phys.net/9/1037/2009/.

Stavrakou, T., Müller, J.-F., De Smedt, I., Van Roozendael, M., Kanakidou, M., Vrekoussis, M., Wittrock, F., Richter, A., and Burrows, J. P.: The continental source of glyoxal estimated by the synergistic use of spaceborne measurements and inverse modelling, Atmos. Chem. Phys. Discuss., 9, 13593-13628, $2009 b$, http://www.atmos-chem-phys-discuss.net/9/13593/2009/.

Tsigaridis, K. and Kanakidou, M.: Global modelling of secondary organic aerosol in the troposphere: a sensitivity analysis, Atmos. Chem. Phys., 3, 1849-1869, 2003,

http://www.atmos-chem-phys.net/3/1849/2003/.

Tsigaridis, K. and Kanakidou, M.: Secondary organic aerosol importance in the future atmosphere, Atmos. Environ., 41, 46824692, doi:10.1016/j.atmosenv.2007.03.045, 2007.

Tsigaridis, K., Lathière, J., Kanakidou, M., and Hauglustaine, D. A.: Naturally driven variability in the global secondary organic aerosol over a decade, Atmos. Chem. Phys., 5, 1891-1904, 2005, http://www.atmos-chem-phys.net/5/1891/2005/.

Volkamer, R., Platt, U., and Wirtz, K.: Primary and secondary glyoxal formation from aromatics: Experimental evidence for the bicycloalkyl-radical pathway from benzene, toluene, and pxylene, J. Phys. Chem. A, 105, 7865-7874, 2001.

Volkamer, R., Spietz, P., Burrows, J., and Platt, U.: High-resolution absorption cross-section of glyoxal in the UV-vis and IR spectral ranges, J. Photochem. Photobiol. a-Chemistry, 172, 35-46, 2005.

Volkamer, R., Molina, L. T., Molina, M. J., Shirley, T., and Brune, W. H.: DOAS measurement of glyoxal as an indicator for fast VOC chemistry in urban air, Geophys. Res. Lett., 32, L08806, doi:10.1029/2005g1022616, 2005.

Volkamer, R., Martini, F. S., Molina, L. T., Salcedo, D., Jimenez, J. L., and Molina, M. J.: A missing sink for gas-phase glyoxal in Mexico City: Formation of secondary organic aerosol, Geophys. Res. Lett., 34, L19807, doi:10.1029/2007g1030752, 2007.

Volkamer, R., Jimenez, J. L., San Martini, F., Dzepina, K., Zhang, 
Q., Salcedo, D., Molina, L. T., Worsnop, D. R., and Molina, M. J.: Secondary organic aerosol formation from anthropogenic air pollution: Rapid and higher than expected, Geophys. Res. Lett., 33, L17811, doi:10.1029/2006g1026899, 2006.

Vountas, M., Rozanov, V. V., and Burrows, J. P.: Ring effect: Impact of rotational Raman scattering on radiative transfer in earth's atmosphere, J. Quant. Spectr. Radiat. T., 60, 943-961, 1998.

Vountas, M., Dinter, T., Bracher, A., Burrows, J. P., and Sierk, B.: Spectral studies of ocean water with space-borne sensor SCIAMACHY using Differential Optical Absorption Spectroscopy (DOGS) (vol 3, pg 429, 2007), Ocean Science, 3, 483-483, 2007.

Vrekoussis, M., Kanakidou, M., Mihalopoulos, N., Crutzen, P. J., Lelieveld, J., Perner, D., Berresheim, H., and Baboukas, E.: Role of the $\mathrm{NO}_{3}$ radicals in oxidation processes in the eastern Mediterranean troposphere during the MINOS campaign, Atmos. Chem. Phys., 4, 169-182, 2004,

http://www.atmos-chem-phys.net/4/169/2004/.

Vrekoussis, M., Mihalopoulos, N., Gerasopoulos, E., Kanakidou, M., Crutzen, P. J., and Lelieveld, J.: Two-years of $\mathrm{NO}_{3}$ radical observations in the boundary layer over the Eastern Mediterranean, Atmos. Chem. Phys., 7, 315-327, 2007, http://www.atmos-chem-phys.net/7/315/2007/.

Wang, Y. H., Jacob, D. J., and Logan, J. A.: Global simulation of tropospheric O-3-NOx-hydrocarbon chemistry 3. Origin of tropospheric ozone and effects of nonmethane hydrocarbons, J. Geophys. Res.-Atmos., 103, 10757-10767, 1998.

Wang, Y. H., Logan, J. A., and Jacob, D. J.: Global simulation of tropospheric O-3-NOx-hydrocarbon chemistry 2. Model evaluation and global ozone budget, J. Geophys. Res.-Atmos., 103, 10727-10755, 1998.

Warneck, P.: Multi-phase chemistry of C-2 and C-3 organic compounds in the marine atmosphere, J. Atmos. Chem., 51, 119-159, doi:10.1007/s10874-005-5984-7, 2005.
Wiedinmyer, C., Guenther, A., Harley, P., Hewitt, N., Geron, C., Artaxo, P., Steinbrecher, R., and Rasmussen, R.: Global Organic Emissions from Vegetation, in: Emissions of Atmospheric Trace Compounds, edited by: Granier, C., Artaxo, P., and Reeves, C., Kluwer Academic Publishers, Dordrecht, The Netherlands, p. 544, 115-170, 2004.

Wiedinmyer, C., Greenberg, J., Guenther, A., Hopkins, B., Baker, K., Geron, C., Palmer, P. I., Long, B. P., Turner, J. R., Petron, G., Harley, P., Pierce, T. E., Lamb, B., Westberg, H., Baugh, W., Koerber, M., and Janssen, M.: Ozarks Isoprene Experiment (OZIE): Measurements and modeling of the "isoprene volcano", J. Geophys. Res.-Atmos., 110, D18307, doi:10.1029/2005jd005800, 2005.

Williams J: Organic trace gases in the atmosphere, an overview. Environ. Chem. 2004, 1, 125-136, doi:10.1071/EN04057, 2004

Wittrock, F., Richter, A., Oetjen, H., Burrows, J. P., Kanakidou, M., Myriokefalitakis, S., Volkamer, R., Beirle, S., Platt, U., and Wagner, T.: Simultaneous global observations of glyoxal and formaldehyde from space, Geophys. Res. Lett., 33, L16804, doi:10.1029/2006gl026310, 2006.

Wittrock, F.: The Retrieval of oxygenated volatile organic compounds by remote sensing techniques, $\mathrm{PhD}$ Thesis, Bremen University, 2006.

Yu, S. C.: Role of organic acids (formic, acetic, pyruvic and oxalic) in the formation of cloud condensation nuclei $(\mathrm{CCN})$ : a review, Atmos. Res., 53, 185-217, 2000.

Zhou, X. L. and Mopper, K.: Apparent Partition-Coefficients of 15 Carbonyl-Compounds between Air and Seawater and between Air and Fresh-Water - Implications for Air Sea Exchange, Environ. Sci. Technol., 24, 1864-1869, 1990.

Zhou, X. L. and Mopper, K.: Photochemical production of lowmolecular-weight carbonyl compounds in seawater and surface microlayer and their air-sea exchange, Marine Chem., 56, 201213, 1997. 